\title{
Atalık Buğdaylara Dönüş ve Öncü Girişimler
}

\author{
Mesut Yüce Yıldız* \\ Tayfun Özkaya**
}

\section{Özet}

Son yıllarda güvenilir gıda tüketimi isteği ve ekolojik kaygılar dünyada ve ülkemizde giderek artmaktadır. Özellikle 1960'lardan sonra buğday dahil birçok üründe yapılan ıslah çalışmaları ve bunlarla birlikte artan kimyasal gübre ve tarım ilaçları kullanımı beslenme ve çevre açısından bazı hatalar yapıldığına dair eleştirileri öne çıkarmaktadır. Kötü beslenme ve artan obezite dikkatleri çekmektedir. Buğday çeşitleri ve değişen üretim yöntemleri, un ve ekmek üretim teknolojileri üzerinde yeniden durulmakta ve yerel buğdaylar tekrar gündeme gelmeye başlamaktadır.

Türkiye'nin buğdayın kültüre alındığı ilk yer olması ve buğday tüketiminin beslenme açısından dünya çapında önemli bir konu haline gelmesi, buğday üretimi ve tüketiminde yerel buğday çeşitlerine ayrı bir önem kazandırmaktadır. Endüstriyel buğdaya alternatif olarak yerel çeşitlerle buğday üretimi yaygınlaşmakta ve tüketim açısından bir talep oluşmaktadır. Yerel buğday üretimi için üreticiler bir araya gelerek değişik kuruluşlar oluşturmakta ve üretimi yaygınlaştırmanın yollarını aramaktadır. Bu çalışma, endüstriyel buğdaya alternatif olarak yerel buğday ile un, bulgur vb. ürünlerin geliştirilmesi ile ilgili faktörleri ortaya koymaya çalışmaktadır. Bu bağlamda çalışmanın amacı, Çanakkale, Balıkesir ve Kars illerinde yerel buğday çeşitlerinin üretimini yapan grup ve derneklerin gerçekleştirdiği üretim ve pazarlama sürecini incelemektir. Çalışmanın ana materyalini bu illerde bulunan üreticiler ile gerçekleştirilen görüşmeler oluşturmaktadır.

Anahtar sözcükler: Yerel buğday, ekmek, Çanakkale Ekolojik Yaşam İnisiyatifi (ÇAYEK), Balıkesir Yaşam Dostu Ürün Dayanışma Grubu, Kars Boğatepe Çevre ve Yaşam Derneği

\section{Abstract}

\section{Return to Ancestral Wheats and Pioneering Initiatives}

In recent years, the demand for reliable food consumption together with ecological concerns increases in the world and in Turkey. Breeding practices that have been introduced in many agricultural products including wheat, particularly since the 1960s, and the use of chemical fertilizers and pesticides lead to criticisms that mistakes have been made in terms of nutrition and environment. Malnutrition and increased obesity are highlighted as specific consequences. Wheat varieties and changing production methods are reconsidered along with flour and bread production technologies, and local wheats are coming to the agenda again.

The importance of local wheat varieties in wheat production and consumption increase in parallel with the increasing importance of wheat consumption around the world in terms of nutrition. Being the first geographical location where wheat entered into culture, Turkey has an exceptional place in this context. As an alternative to industrial wheat, production with local varieties becomes widespread and subject of increasing demand. Producers come together and form various organizations to search for ways to spread local wheat production.

* Ege Üniversitesi, Tarım Ekonomisi Bölümü

** Ege Üniversitesi, Tarım Ekonomisi Bölümü 
This study aims to reveal the factors related to the development of wheat products based on local varieties such as flour, bulgur, etc., as an alternative to industrial wheat. In this context, this study will investigate the production and marketing practices of groups and associations formed by local producers of wheat varieties in Çanakkale, Balıkesir and Kars provinces. The main material of the study consists of interviews with producers in these provinces.

Keywords: Local wheat, bread, Çanakkale Ecological Life Initiative, Balıkesir Prolife Agricultural Solidarity Group, Kars Boğatepe Environment and Life Association

\section{Giriş}

İnsan-buğday ilişkisi olasılıkla günümüzden 14 bin y1l önce Verimli Hilal'de (Güneydoğu Anadolu, Mezopotamya) başlamıştır. Arpa ile insanın yetiştirdiği ilk bitkilerden biri olan buğdayın günümüzdeki yaygınlığ 1 daha iyi anlaşılabilir. ${ }^{1}$

Buğdayın yetiştirilmesi insanın toplumsal yaşamında ciddi değişikliklere neden olmuştur. İnsanın yerleşik yaşama geçişinde buğdayın etkisi arkeolojik ve arkeometrik olarak kanıtlanmıştır. İlk devlet ve ilk kentlerin görüldüğü, s1nıflı toplum ve artı ürünün gözlendiği Mezopotamya'da, bu kavramların anlam kazanmasında buğdayın evcilleştirilmesi veya başka bir deyimle kültüre alınması büyük öneme sahiptir. ${ }^{2}$

Buğdayın kültüre alınmasıyla beraber çiftçiliğin de ilk defa daha belirgin uygulandığı gözlenmektedir. Ancak Göbeklitepe'de yapılan arkeolojik çalışmalarda avcı-toplayıcı insanların da buğdayla olan ilişkisi ortaya çıkmıştır:

Göbeklitepe bu tarihlerde halen avcı ve toplayıcıların dünyasına ait bir yer olmakla birlikte; Neolitik Devrim'i gerçekleştirmek ve bilinçli üretim yoluyla besin sağlamada temel değişiklikleri getirecek çiftçiliğe dayalı bir yaşam tarzını keşfetmek üzere olan avcı bir kültürün kapanış evresini temsil etmektedir. ${ }^{3}$

İnsanın buğdayı kullanımı bugünkü durumundan farklıdır. Yapılan araştırmalarda buğdayın ve diğer tahılların insanlar tarafından zor öğütüldüğü tespit edilmiştir. MÖ 11000-9300 arasında tahıl kavurma yerleri gözlenmiş ve insanların buğdayı kolay sindirebilmek için kavurarak kullandığı tespit edilmiştir. Yine kolay sindirimi açısından öğütme taşları kullanılmıştır. Bu sayede ekmeğin kaya sertliğinde olmaması sağlansa da ekmeğin arası kum taneleri ile dolu olduğu için yine öğütülürken zorlanıldığı söylenmektedir. Buğdayın bu şekilde kullanımı öğütme sorunu yanında diş aşınmalarına neden olduğu yapılan arkeolojik çalışmalarda bulunan iskeletlerin diş ve ağız yapılarından tespit edilmiştir. ${ }^{4}$

Buğdayla insanın ilişkisi 14 bin yıldır birçok değişime uğramıştır. Buğday türleri, çeşitleri ve tipleri bir arada düşünüldüğünde bu değişikliklerin sayısı

1 Ahmet Uhri, Boğaz Derdi: Arkeolojik, Arkeobotanik, Tarihsel ve Etimolojik Veriler Işı̆̆ında, Tarım ve Beslenmenin Kültür Tarihi (İstanbul: Ege Yayınları, 2011).

2 Uhri, Boğaz Derdi.

3 Klaus Schmidt, Taş Çă̆ı Avcılarının Gizemli Kutsal Alanı, Göbekli Tepe, En Eski Tapınağı Yapanlar, çev. Rüstem Arslan (İstanbul: Arkeoloji ve Sanat Yayınları, 2014).

4 Uhri, Boğaz Derdi. 
milyonları bulmaktadır. ${ }^{5}$ Buğday insanla beraber bir yerden diğerine taşınmış ve bulunduğu her bölgede adaptasyon yeteneği göstererek, yetiştirildiği çevreye uyum sağlamıştır. Buğdayın bugün 220 milyon hektar (ha) üzerinde bir alanda yetiştiriliyor olmasi ${ }^{6}$ ve insanın, gelişiminin bütün süreçlerinde onu beraberinde taşıması, evrimsel başarısının en büyük ispatıdır.?

Tarihte buğdayın gelişimi ile uygarlıkların gelişimi birbirine paralel şekilde ilerlemiştir. Buğdayın gelişimi ve yayılımı tamamen insana bağlı olmuştur. Sürecin bu şekilde işlemesi, yani insanın yayıldı̆̆ı her yere buğdayı da götürmesi ile 17 bin farklı buğday çeşidi ortaya çıkmıştır. ${ }^{8}$

Buğday, güney Rusya, Amerika Birleşik Devletleri, Norveç, Finlandiya ve Arjantin'e kadar çok geniş bir yetiştirilme alanına sahiptir. Bugün yetiştirilen modern buğdayların atası olarak Triticum aestivum var. Aestivum buğdayı belirtilmektedir. Modern buğday tür ve çeşitlerinin seçiminde buğday proteini olan gluten miktarı ve dane sertliği etkin olmuştur. Gluten, ekmek yapımı sırasında karbondioksit gazını tutarak hamurun kabarmasını ve pişmesini mümkün kılar. Son zamanlarda buğdayda bulunan gluten proteini intoleransı ile ilgili ciddi sağlık ve gıda tartışmaları yapılmaktadır.

\section{Buğdayın Dönüşümü: Yeşil Devrim}

1948-1951 yılları arasında Marshall Planı kapsamında, gelişmiş ülkelerce özellikle gelişmekte olan ülkelere yapılan yardımlar tarımda büyük bir dönüşüme neden olmuştur. Tarımsal mekanizasyonun artması, tarımda kimyasal ilaç ve gübre kullanımının egemen olması, üretilen ürünlerin veriminin artması, üretimde tek tipleşme vb. birçok gelişme yaşanmıştır. Bu süreç bir süre sonra yeşil devrim denen sürece ön ayak olmuştur. Yeşil devrimin en önemli gelişmelerinden biri ise Norman Borlaug tarafından yapılan Meksika cüce ve yarı-cüce buğdaylarından yararlanılarak yapılan ıslah çalışmalarıdır.

19. yüzyılda Japon bilim insanları, Daruma adlı yerel buğday çeşitlerini Kırmızı Kışlık Türk buğdayıyla melezleyerek yüksek verimli Norin 10 çeşidini geliştirmiştir. ${ }^{9}$ Amerikalı bilim insanları, Norin 10 çeşidini yerel Amerikan çeşidi Brevor ile melezlemiş ve oluşan hatları Meksika'ya götürmüştür. Bu bitkiler Meksika'da Norman Borlaug ve arkadaşları tarafından denemeye alınmış ve yüksek verimli çeşitler elde edilmiştir. ${ }^{10}$

Bu yarı-cüce buğdayların geliştirilmesindeki başarı, özellikle azotlu güb-

5 Mirza Gökgöl, Türkiye Buğdayları. Die Türkischen Weizen, 2. cilt (İstanbul: Yeşilköy Tohum Islah Enstitüsü, 1939).

6 FAOSTAT, "Production Quantities of Wheat by Country", http://faostat3.fao.org/browse/Q/ QC/E, erişim tarihi 5 Mart 2016.

7 Uhri, Boğaz Derdi.

8 Gordon Kimber ve Moshe Feldman, Wild Wheat: An Introduction Special Report 353 (Columbia: University of Missouri College of Agriculture, 1987).

9 W. Powell, E. P. Wilhelm, M. I. Boulton,T. E. S. Barber, A. J. Greenland, “Genotype Analysis of the Wheat Semidwarf Rht-B1b and Rht-D1b Ancestral Lineage", Plant Breeding 132, no. 6 (2013): 539-545.

10 WWF, Türkiye'nin Buğday Atlası (İstanbul: Doğal Hayatı Koruma Vakfı, 2016). 
re kullanılması durumunda yatmaması olarak gösterilmiştir. ${ }^{11}$ Ancak bu yeni tohumların tam potansiyeli sadece toprakta iyi bir hazırlık yapılması, büyük miktarda gübre kullanımı, doğru oran ve ekim derinliği gibi uygun tarımsal uygulamalar izlendiğinde ve su, yabani ot ve zararlı kontrolünün kullanımın doğru olması ile gerçekleşebilmektedir. ${ }^{12}$

Meksika buğday tohumları 1964'te 50 dönümlük bir arazide yetiştiriliyor iken, beş yıl içerisinde, 1968'de 14 milyon 554 bin dönüm arazide yetiştirilmeye başlanmıştır. Bu üretimi en çok benimseyen ülkeler Hindistan, Pakistan ve Türkiye olmuştur. ${ }^{13}$ Yeşil devrim genel çerçevede büyük bir başarı olarak kabul edilse de aslında, özellikle az gelişmiş ülkelerin dişa bağımlılığını arttırmış ve tarım politikalarındaki bağımsızlığını azaltmıştır.

\section{Yeşil Devrim, Buğday ve Türkiye}

Türkiye'de Meksika cüce buğdayları 1967 yılında Sonora-64 adı ile yetiştirilmeye başlanmıştır. İlk denemeler dönemin Tarım Bakanı Bahri Dağdaş önderliğinde Adana ilinde yapılmıştır. ${ }^{14}$ Dönemin Tarım Bakanı tarafından artık Türkiye'nin buğday ihraç edebilecek potansiyeli olacağı söylenmiştir. Ancak durumlar böyle gelişmediği gibi beslenme konusunda da ciddi sorunlar ortaya çıkmıştır.

Osman N. Koçtürk 1969'da yazdığı Açlık Korkusu adlı kitabında, özellikle Sonora-64 buğdayının tarım politikası açısından ciddi sonuçlarını detaylıca aktarmıştır.

Açlık korkusuna düşürülmüş olan Türkiye bu korkuyu tanımadığı devrede buğday ihraç ederken bugün Sonora-64 buğdayını denemiş, verimi artırmak için tohumluk, gübre, ilaç, araç ve gereç için yabana milyonlarca dolar ödedikten sonra 1969 yılında 850.000 ton buğday ithaline mecbur kalmıştır. Korkunun ürünü olarak Dünya Bankası'ndan alınacak olan 3,5 milyarlık ve \%6,5 faizli kredi ile Türkiye'ye sokulacak olan yüksek verimli inekler, Sonora denemesinden daha iyi sonuç vermeyecek ve Türkiye'nin borçları daha da artacaktır..$^{15}$

Islah çalışmalarından elde edilen buğdayları kullanmadan önce Türkiye, özellikle 1950-1960 arasında buğday ihraç ederken buğday ithal eder duruma gelmiş ve bu dönüşüm bütün tahıl üretimine yansımıştır (Çizelge 1). Durum 1967'de ekilmeye başlayan Sonora-64 buğdayı ile daha vahim hale gelmiştir (Çizelge 2). Kimyasal gübre ve ilaçlarla yüksek verim elde etmeye dayalı yapılmaya çalışılan üretim, en başta verim açısından olumlu sonuçlar doğurmuş olsa da maliyet artışından dolayı ekonomik olarak verim düşüklügüunden daha çok etkilenmiştir. Bu durum ülke ekonomisini de sarsmış ve dışa bağımlılık yaratmıştır. 1969 yılında verimlerin \%10-30 arası düşmesi ve üretimde beklenen

11 John H. Perkins, Geopolitics and Green Revolution: Wheat, Genes, and the Cold War (New York: Oxford University Press, 1997).

12 Ulaş Karakoç, "Productivity and Structure in Turkish Agriculture 1950-1991" (Yüksek Lisans Tezi, London School of Economics and Political Science, Londra, 2008).

13 Karakoç, "Productivity and Structure in Turkish Agriculture 1950-1991".

14 Osman Nuri Koçtürk, Açlık Korkusu (Ankara: TMMOB Ziraat Mühendisleri Odası, 2009).

15 Koçtürk, Açlık Korkusu, 12. 
hedefin tutturulamaması, dışarıdan buğday talep edilmesine neden olmuştur. ${ }^{16}$ Buğdayda yaşanan bu değişim diğer tarım ürünlerini de etkilemiştir. 1953-1962 yılları arasında Türkiye Amerika'dan buğday ile geniş çapta yağ ithalatına da başlamıştır. ${ }^{17}$

Çizelge 1 1953-1962 Yılları Arasında Türkiye'nin Tahıl İthal ve İhraç Durumu (Yıl/Ton)

\begin{tabular}{|c|c|c|}
\hline Yıllar & Tahıl İthalatı & Tahıl İhracatı \\
\hline 1953 & 1000 & 896000 \\
\hline 1954 & - & 1063000 \\
\hline 1955 & 389000 & 362000 \\
\hline 1956 & 198000 & 12000 \\
\hline 1957 & 445000 & 221000 \\
\hline 1958 & 60000 & 664000 \\
\hline 1959 & 6000 & 73000 \\
\hline 1960 & 99000 & 88000 \\
\hline 1961 & 376000 & 10000 \\
\hline 1962 & 690000 & \\
\hline
\end{tabular}

Kaynak: Mehmet Ali Bagana, Mediterranea 6 (1965) ve Osman N. Koçtürk, İşçinin Beslenmesi ve Milli Prodüktivite (Ankara: Türk-İş Yayınları 1965), aktaran Osman Nuri Koçtürk, Açlık Korkusu (Ankara: TMMOB Ziraat Mühendisleri Odası, 2009), 45.

Çizelge 2 1967-1975 Yılları Arasında Türkiye Tahıl İthalat ve İhracat Durumu (Yıl/Ton)

\begin{tabular}{|c|c|c|}
\hline Yıllar & Tahıl İthalatı & Tahıl İhracatı \\
\hline 1967 & 14157 & 12636 \\
\hline 1968 & 5 & 9146 \\
\hline 1969 & 442343 & 1216 \\
\hline 1970 & 1161300 & 4932 \\
\hline 1971 & 704603 & 350135 \\
\hline 1972 & 11377 & 31258 \\
\hline 1973 & 110406 & 2606 \\
\hline 1974 & 1275945 & 7251 \\
\hline 1975 & 559521 & 10430 \\
\hline
\end{tabular}

Kaynak: FAOSTAT, 2016, http://faostat3.fao.org/browse/Q/QC/E, erişim tarihi 5 Mart 2016

16 Koçtürk, Açlık Korkusu, 41.

17 Koçtürk, Açlık Korkusu, 44. 
İthal edilen yeni buğday tohumlukları, hükümet tarafından hiçbir denemeye tabii tutulmadan üretime konmuştur. Tarım Bakanlığı, ithal edilecek tohumluğun miktarı için, iklim ve ekim etütleri yaptırmamıştır. Bu sebepten ithal edilen tohumluk buğday, gerçek ihtiyaçtan çok fazla olmuştur. Çiftçiler, haklı olarak bu tohumluklara karşı, bakanlığın beklediği ilgi ve itibarı göstermemişlerdir. Hiçbir etüde dayanmadan ithal edilen tohumluk bu sebepten de ayrıca fazlalık göstermiştir. Tarım Bakanlığı, Meksika buğdayının memleketimiz iklim şartlarına, zararlı ve hastalıklara karşı mukavemet derecesinin ve mücadele masraflarının neler olacağını tespit eden bir inceleme de yaptırmamıştır. Bu husus Amerika'ya giden heyete, bitki hastalıkları ile ilgili bir uzmanın katılmamış olması ve gelen buğdayların da zararlılarla bulaşık çıkması ile sabit olmuştur. Bundan başka bu buğdayların besleme değerleri üzerinde de durulmamıştır. ${ }^{18}$

\section{Buğday Tartışmaları ve Yerel Buğdayların Önemi}

1960'lardan bu yana devam eden süreç hem dünyada hem Türkiye'de genel akademik çerçeve, buğdayın verimlilik ve ekonomik açıdan başarı göstermiş olduğunu düşündürmekte ve bunun üstüne yoğunlaşmaktadır. Tarihsel araştırmalar, modern buğdayların aslında sanıldığı gibi makro-ekonomi ve verim açısından başarılı bir örnek olmadığını göstermektedir. Verim ve ekonomik büyüme miktarları sürekli artış göstermiş olsa da bunun bedelleri olmuştur.

Tarımın tekelleşmesi, bitkilerin daha fazla kimyasal ilaç, gübre gibi girdilerle yapılması küçük üreticinin yok olması gibi konular gündeme gelmeye başlamıştır. Özellikle son dönemlerde artarak devam eden sağlıklı beslenme tartışmaları buğday üretimini doğrudan etkilemiştir. Buğdaydaki gluten proteinin oluşturduğu bazı etkiler hekimler, beslenme uzmanları, biyologlar ve ziraat mühendisleri tarafından insan sağlığı açısından tehlikeli olarak değerlendirilmektedir. O kadar ki yapılan analizlerde glutenin insanlarda bağımlılık yaptığı ve obezitenin temel sebebi olarak görüldüğü söylenmektedir. ${ }^{19}$ Bu yüzden eski yabani buğday çeşitlerinin hem daha sağlıklı hem de ekonomik açıdan yetiştirilmeye daha uygun olduğu vurgusu yapılmaktadır. Modern ıslah çalışmalarının monokültür üretimi teşvik edici şekilde yapılması, biyoçeşitlilik açısından da tartışılan bir konudur.

Kardiyoloji uzmanı William Davis 2011 yılında yazdığ $(2014$ yılında Türkçeye çevrilen) Buğday Göbeği adlı kitabında modern buğdayın bazı yan etkilerini açıklamıştır. Davis, yeşil devrim döneminde ıslah edilen buğdayların obezite, diyabet, bağışıklık sistemi problemleri, özellikle çölyak hastalığı ve psikiyatrik bazı rahatsızlıklara etkisi olduğunu savunmuştur.

Buğdayın şizofreni hastaları üzerindeki etkilerini araştıran bir çalışmada, kıtlık yüzünden ekmek tüketiminin az olmasından dolayı şizofreni tanısıyla

18 Koçtürk, Açlık Korkusu, 79.

19 William Davis, Buğday Göbeği, çev. Ekin Duru (İstanbul: Pegasus Yayınları, 2014). 
hastaneye yatanların sayısının, savaştan sonra artan ekmek tüketimi ile artan şizofreni vakalarına oranla çok daha az olduğu görülmüştür. ${ }^{20}$

Bir diğer araştırma buğday ürünlerinin insülin miktarı üzerindeki etkisi hakkındadır. William Davis buğdayın kan şekerini yükseltici etkisini şöyle açıklamaktadır:

Glisemik indeks beslenme uzmanlarının bir yiyeceğin tüketildikten 90 ila 120 dakika sonra kan şekerini ne kadar yükselttiğini belirlemeye yarayan bir ölçümdür. Bu ölçüte göre, tam tahıllı ekmeğin glisemik indeksi 72, sofra şekerinin 59'dur (Bazı laboratuvarlar da bu sayı 65 olarak bulunmuştur). Öte yandan, barbunya fasulyesinin 51, greyfurtun ise 25 olarak saptanmışken karbonhidrat içermeyen somon balığı ve ceviz gibi yiyeceklerin glisemik indeksi sıfırdır. Bu tür gıdalar kan şekerini hiç etkilemez. Aslında birkaç istisna dışında, glisemik indeksi buğdaydan elde edilen gıdalar kadar yüksek çok az gıda maddesi vardır. ${ }^{21}$

Buğdayın bütün bu zararlarının birçoğuna özellikle gluten proteini sebep gösterilmiştir. Gluten terimi iki protein ailesini kapsamaktadır. Bunlar gliadinler ve gluteninlerdir. Gliadinler, çölyak hastalığında bağışıklığı tetikleyen temel proteinlerdir. Yapılan ıslah çalışmaları etkisi olarak Çölyak hastalığı son 50 yılda dört kat artmıştır. Bu durum ıslah edilerek üretilen buğdayların, evrimsel olarak insanın yapısına uygun olmadığı anlamına gelmektedir. ${ }^{22}$

Yerel buğday çeşitlerinin bütün bunlar açısından önemi gluten miktarının modern çeşitlere göre düşük olmasıdır. Bunun sebebi ise yerel çeşitlerin birçoğunun diploid yapıya sahip olmasıdır. Bunun anlamı kromozom miktarı ve yapısına göre gluten oranları doğru orantılıdır. Mesela A genom içeren Siyez buğdayı ufak kromozom yapısına sahip olduğu ve 14 kromozom içerdiği için az sayıda gluten içerir. Fakat A ve B genomlarına sahip Kavlıca buğdayı 28 kromozom içerdiğinden daha çok çeşit glutene sahiptir. ${ }^{23}$ Bununla doğru orantılı olarak insan eliyle melezlenmeden önce bile A, B ve D genomlarma sahip Triticum aestivum en geniş gluten çeşidini içerir. Yapay seleksiyon ile yapılan melezlemeler ise Triticum aestivum'un D genomuna odaklanmıştır. D genomu arttırılarak unun daha pişkin ve estetik bir görünüme sahip olması sağlanmıştır. D genomu bu yüzden gluten çeşitlerinin en çok değişime uğradığı alandır. ${ }^{24}$

Yapılan ıslah çalışmaları ile gluten proteinin yapısında değişimler meydana

20 F. C. Dohan, "Wheat 'Consumption' and Hospital Admissions for Schizophrenia during World War II: A Preliminary Report", The American Journal of Clinical Nutrition 18, no. 1 (Ocak 1966): 7-10.

21 Davis, Buğday Göbeği.

22 O. Molberg, A. K. Uhlen, T. Jensen vd., "Mapping of Gluten T-cell Epitopes in the Bread Wheat Ancestors: Implications for Celiac Disease", Gastroenterology 128, no. 2 (Şubat 2005): 393-401.

23 Peter R. Shewry, Nigel G. Halford, Peter S. Belton, Arthur S. Tatham, "The Structure and Properties of Gluten: An Elastic Protein from Wheat Grain", Philosophical Transactions Royal Society London B 357, no. 1418 (Şubat 2002): 133-142.

24 Davis, Buğday Göbeği. 
gelmiştir. Bu değişimin ise nasıl sonuçlar doğurduğuna dair detaylı araştırmalar halen yetersizdir. Ancak yapılan araştırmalarda özellikle modern buğday çeşitlerinde gluten proteini yapısındaki bu değişimin çölyak hastalığı ile doğrudan ilişkisi olduğu düşünülmektedir:

Melez bir buğdayla onu oluşturan iki türün proteinlerinin tahlili, melezdeki proteinlerin yaklaşık yüzde 95'inin ebeveyniyle aynı olmasına karşın yüzde 5 kadarının hiçbir ebeveynde bulunmadığını ortaya koymuştur. ${ }^{25}$

Buradan çıkan sonuç, buğdayın melezleme sırasında önemli yapısal değişime uğradığıdır. Hatta yapılan bir melezleme deneyinde melezin ebeveynde olmayan 14 proteine sahip olduğu gözlenmiştir. Islah çalışmalarında on binlerce melezleme yapıldığı düşünüldüğünde gluten proteinin yapısında muazzam farklılıkların ortaya çıktığı da görülebilir. Sonuçlarının ne olabileceği ise umursanmamaktadır. ${ }^{26}$ Diğer önemli nokta ise modern ıslah çalışmalarının buğday mineral madde miktarlarında yarattığı önemli değişimdir. Modern buğdaylar yüksek gluten proteini ve verim hedefine dayalı üretilse de mineral madde açısindan zenginliğini kaybetmektedir. ${ }^{27}$

Özellikle beslenme üzerinden yürüyen bu tartışmalar disiplinler arası olarak yer bulsa da birbirinden bağımsız farklı görüşler ortaya çıkarmıştır. Diyetisyenler ve doktorlar buğdayın üretim sürecine ya da tarımsal konumuna dikkat etmeyerek sadece gıda ürünü olarak tartışmaktadır. Biyologlar ve genetikçiler buğdayın evrimsel sürecini dikkate alarak tartışmaları biyoçeşitlilik ekseninde sürdürmektedir. Tarımcılar ise son zamanlarda doktorların ve diyetisyenlerin yürüttüğü tartışmalara ağırlık vererek, buğday üretiminin ekonomi ve beslenmedeki rolü üzerinde muhalefet etmektedirler. Tarımcılar arasında sağlık endişelerinin yersiz olduğu anlayışı hakimdir. Onlar açısından buğday başat tüketim malzemesi olduğundan ve nüfusun giderek artmasından dolayı buğday üretiminin ancak modern ılah buğdayları ile yapılabileceği anlayışı hâkimdir.

Her görüşün belli artıları olmasına rağmen buğday ürünü tüketmeli ya da tüketmemeliyiz ekseninde tartışmalar sürdürülmektedirler. Üretim ve tüketim sürecinde bu görüşlerin ortaklaşmasını sağlayacak çabalar mevcuttur. Yani buğday ürünlerinin insan sağlı̆̆ üzerinde yarattığı olumsuz koşulları ortadan kaldırarak üretimi devam ettirebilmenin yolu bulunmaktadır. Yerel buğday

25 Y. Yingyin, N. Zhongfu, Z. Yinhong, C. Yan, D. Yuhua, H. Zongfu, L. Zhiyong, L. ve S. Qixin, "Identification of Differentially Expressed Genes in Leaf and Root Between Wheat Hybrid and Its Parental Inbreds Using PCR-based cDNA Subtraction", Plant Molecular Biology 58 (2005): 367-384.

26 X. Gao, S. W. Liu, Q. Sun, G. M. Xia, "High Frequency of HMW-GS Sequence Variation Through Somatic Hybridization Between Agropyron Longatum and Common Wheat", Planta 213, no. 2 (Ocak 2010): 245-50.

27 Mevlüt Akçura, Onur Hocaoğlu, Hasan Kılıç, Kağan Kökten, “Karadeniz Bölgesine Ait Yerel Ekmeklik Buğday Hatlarının Tanedeki Besin Elementleri İçerikleri Yönünden Tescilli Ekmeklik Buğday Çeşitleri ile Karşılaştırılması", Türkiye 10. Tarla Bitkileri Kongresi, cilt 1, no 1 (Konya, 2002), 53-60. 
çeşitleri ile üretim bu konuda önemli bir çabayı oluşturmaktadır. Özellikle Türkiye açısından mevcut gruplar, dernekler ve bu grupların sağladığı gıdaları tüketen tüketici grupları, buğdayın bu olumsuz gidişatına karşı alternatif bir yol sunmaktadır. Buğday ürünlerinin sağl1klı biçimde, gluten miktarı düşük, kimyasal madde bulunmayan ve özellikle küçük üretici kalkındırmaya yönelik, tüketebilmenin yolu bu tüketici grupları ile sağlanmaktadır.

\section{Materyal ve Ülkemizde Yürütülen Çalışmalar}

Çalışmada Çanakkale, Balıkesir ve Kars olmak üzere üç farklı ilde yerel buğday üretimi yapan kurum, dernek ve gruplara bağlı üreticiler ile görüşülmüştür. Çanakkale'de Bayramiç ilçesinde Yeniköy mahallesinde tek bir yerel buğday üreticisi bulunmakta ve yarı yapılandırılmış anket ve yüz yüze görüşmeler ile bilgiler elde edilmiştir. Yerel buğday üretiminin ekimi bu bölgede üretici ile deneyimlenmiş ve gözlemlenmiştir. Balıkesir'de ilk olarak Yaşam Dostu Ürün Dayanışma Grubu kurucusu ve başkanı ile görüşülmüş, grubun gıda üretim süreci, yani buğdayların üreticilerden alınarak ekmeğe, bulgura vb. ürünlere dönüşüp pazara sunuluncaya kadar işleyen süreç detaylıca incelenmiştir. Gruba bağlı olan az sayıda üreticiden üretim verileri elde edilmiştir. Bunun dışında gruba bağlı olmayan ama grubun yerel buğday aldığı, Balıkesir'in farklı köylerinde yaşayan 14 üreticiden bilgiler ve veriler alınmıştır. Kars Boğatepe Çevre ve Yaşam Derneği buğdayın hasadından, bulgura ve una çevirim süreci dernek çatısı altında bulunan üretici ile incelenmiştir. Kars'ta toplam 34 yerel buğday üreticisi ile görüşülmüştür. Görüşmeler, 2016 yılında Ege Üniversitesi Bilimsel Araştırma Projeleri kapsamında desteklenen yüksek lisans tezi çerçevesinde yapılmış, yerel buğdayların sosyal, kültürel ve ekonomik süreçleri incelenmiştir.

Çalışmanın özellikle bu illerde olan dernekler ve üreticiler olarak seçilmesinin nedeni, Çanakkale'den Kars'a yani üretimin tek kişiden daha kolektif bir yapıya dönüşümünün izlenebilme olanağı olmasıdır. Bunun yanında, üretimden pazara tüm dönüşüm süreçlerini inceleme şansının bulunmasıdır.

Üreticiler ve diğer paydaşlarla yapılan görüşmelerin dışında Türkiye'de yerel buğday üretimi, tüketimi ile ilgili literatür detaylıca incelenmiştir.

“Ege Bölgesi'nde tarımsal biyoçeşitliliğin korunması ve sürdürülebilir kullanımı açısından yerel buğday çeşitlerinde üretici ve tüketici duyarlıklarının ölçülmesi" adlı çalışma yerel buğday çeşitlerinin üretim ve tüketim alanını ekonomik yönden analiz etmektedir. ${ }^{28} \mathrm{Bu}$ çalışmada koşullu değerleme yöntemi hem yerel buğday üreticilerinin kabul istekliliği hem de yerel buğday ürünleri tüketmek isteyen tüketicilerin ödeme istekliliği ortaya konmaya çalışılmıştır. Araştırma Ege Bölgesi'nde Afyon, Kütahya, Uşak ve Manisa illerinde gerçekleş-

28 E. H. Salalı, “Ege Bölgesi'nde Tarımsal Biyoçeşitliliğin Korunması ve Sürdürülebilir Kullanımı Açısından Yerel Buğday Çeşitlerinde Üretici Ve Tüketici Duyarlılıklarının Ölçülmesi" (Doktora Tezi, Ege Üniversitesi, İzmir, 2013). 
tirilmiştir. Seçilen illerde, buğday yetiştirilme alanlarına göre iki ilçe seçilmiş, üreticiler ile yüz yüze görüşmeler ve anket yoluyla buğday verileri toplanmıştır.

Koşullu değerleme senaryosunun en önemli unsurlarından biri, soruların nasıl sorulacağı ile ilgilidir. Anket, cevaplayıcı kişiye belli bir parasal değer sunmaktadır. Farklı fiyatlar karşısında tüketici talebini ölçebilmek için, açık artırma yöntemi ile tüketiciye öncelikle soru ile verilen başlangıç fiyatını ödemeyi kabul edip etmediği sorulmuştur. Fiyatı kabul eden tüketiciye, daha yüksek bir fiyat teklifi sunulurken, kabul etmeyen tüketiciye daha düşük fiyat teklif edilmiştir. Ödeme isteği belli bir noktaya ulaştığında açı arttırma sona erdirilerek, tüketiciye "siz, en son ne fiyat ödemek istersiniz" şeklinde sorulmuştur.

Benzer şekilde üreticiler için de yerel buğday üretmesi karşılığında kendilerine ödenmesini kabul edecekleri miktar saptanmıştır. Bu bilgiler ışığında kurulan belirli modeller ve istatistiki analizler ile üreticilerin ve tüketicilerin yerel buğday konusundaki isteklerinin detaylı ekonomik analizi elde edilmiştir. Üreticilerin ve tüketicilerin yerel buğday üretme, tüketme konusundaki isteklerini belirleyen etkenler saptanmıştır. ${ }^{29}$

"The Value of Wheat Genetic Resources to Farmers in Turkey" ${ }^{30}$ adlı çalışmada seçilen illerde (Eskişehir, Kütahya ve Uşak) toplamda 285 üretici ile anket yolu ile alınan veriler sayesinde, buğday üreticilerinin modern ya da yerel çeşit üretmeyi tercih etme nedenleri ortaya koyulmuştur. Burada en belirleyici etmenler arasında ilki, pazara uzaklığın yerel çeşit ya da modern çeşit yetiştirmede önemli rol oynamasıdır. Pazardan uzaklaştıkça yerel çeşitlerin üretimi artış modern çeşitlerin ise azalış göstermektedir. İkinci bir neden, üreticilere yerel buğday üretimi veya modern buğday üretimini sonlandırma nedenleri sorulduğu zaman şaşırtıcı olarak farklı bakış açılarıyla en belirleyici nedenin verim olduğu sonucuna ulaşılmıştır. Şöyle ki, üretici açısından yerel buğdaylar için verim düşüklüğü ortalama buğday verimine göre düşünülürken (modern çeşitleri içine dahil edecek şekilde), modern çeşitler içinde beklentinin altında, yani maliyetleri ve diğer harcamaları karşılayacak biçimde, kaldığı düşünülmektedir. Bir başka netice ise, üreticilerin modern ve yerel buğday çeşitleri üretme nedenlerinin nitelikleri açısından değerlendirilmesine bakıldığında, modern çeşitlerin verim yönünden tercih edilmesi ağır basarken, yerel çeşitlerin özellikle lezzet ve pişirme kalitesi yönünden tercih edildiği gözlenmiştir. Bunun dışında, kuraklığa ve hastalığa dayanaklılık yönü yerel çeşitlerin tercih edilme nedenlerinden biridir.

Zühre Aksoy tarafından yapılan "Biodiversity and Biotechnology in the Agriculture Sector" adlı çalışma, Türkiye'de buğday üretimini ele alarak, geleneksel (yerel) buğday çeşitlerinin üretiminin biyoçeşitlilik ve biyoteknoloji

29 Salalı, "Ege Bölgesi'nde Tarımsal Biyoçeşitliliğin Korunması".

30 S. B. Brush and E. Meng, "The Value of Wheat Genetic Resources to Farmers in Turkey", Agricultural Values of Plant Genetic Resources içinde, der. R. E. Evenson, D. Gollin ve V. Santaniello (Wallington: CAB International, 1998), 97-113. 
açısından tartışmaktadır. ${ }^{31}$ Çalışmanın ilk kısmında üreticilerin üretimde yerel buğday ya da modern çeşitler kullanma nedenleri üzerinde durulmuştur. Yerel çeşit üreticilerin özellikle dağ köylerinde yaşayan ve yaşlı olan üreticiler olduğu gözlenmiştir. Bunun nedeni, üreticinin hem ürettiği ürüne ait bilgisinin olmas1nın önem arz ediyor olması, hem de yetiştiricilik yaptığı alanın modern çeşitlere uygun olmamasıdır. Bununla beraber Aksoy, özellikle Türkiye'de, Dünya Bankası ve IMF ile yürütülen, 1980'den sonra uygulanan politikaların yerel buğday üretimini olumsuz etkileyen dönüşümü incelemiştir. Yaşanan liberalizasyon verime dayalı üretimi başat konuma getirmiş ve pazar büyük bir dönüşüme uğramıştır. Bu durum tarımda özellikle biyoteknoloji kullanımının dönüşümü, buğdayda genetik modifikasyon ile pestisitlere karşı direnç gösteren yeni buğday çeşitlerinin geliştirilmesini, beraberinde getirmiştir. Tarım firmaları tüm insanlığı besleme söylemi ile verime dayalı, insan sağlı̆̆ını önemsemeyen ve en önemlisi hâkim olan küçük üreticiye dayalı üretimin üzerinde ciddi bir baskı yaratmışlardır. Pazarın büyük bir kısmına bu firmalar egemen olmuştur. Aksoy, Türkiye'de yerel buğday üretimi yapan üreticilerin, biyoçeşitlilik açısından önemini vurgulayarak, biyoteknolojinin yüksek verime dayalı buğday üretimi yerine insan sağlığını düşünen, gıda güvenliği oluşturan bir anlayışta yürütülmesi gerektiğini savunmaktadır.

Yerel buğday çeşitlerinin korunması, son zamanlarda tohum ve gen merkezlerinde ıslah materyali olarak korunması yerine (ex situ) daha çok yerinde üreterek (in situ) koruma şeklinde yapılmaya başlanmış ve yerel buğdayların üretim devamlılığının sağlanabilmesine olanak sağlamıştır. Bu anlamda yapılan en kapsamlı çalışma katılımcı yaklaşımı da kullanarak FAO (Birleşmiş Milletler Tarım ve Gıda Örgütü) tarafından 2009-2014 yılları arasında Türkiye'de yürütülen çalışmadır. Bu çalışma iki kısma ayrılabilir. Birinci kısımda, 2009 ve 2010, 2011 yıllarında CIMMYT (Uluslararası Mısır ve Buğday Geliştirme Merkezi), ICARDA (Kurak Alanlarda Uluslararası Tarımsal Araştırma Merkezi) ve Türkiye'nin de katıldığı ortaklıklar ile "Modern ıslah araçları ve katılımcı seçim yoluyla geleneksel buğday çeşitlerinin ve yerel çeşitlerin kurak arazilerde iyileştirilmesi" başlığı altında çalışmalar yapılmıştır. İkinci kısımda ise, 2012 ve 2013 yıllarında, FAO'nun da bu işbirliğine katılması ile 2014 yılında CIMMYT-ICARDA, FAO ve Türkiye işbirliğiyle proje tamamlanmıştır. Yerel buğday üreticileri ile Türkiye'de 65 ilde yüz yüze görüşmelerle toplam 1873 anket yapılmıştır. Bu yerler, STK'lar, üniversiteler, Tarım İl Müdürlükleri, Tarım, Gıda ve Hayvancılık Bakanlığı gibi farklı kaynaklardan alınan bilgilere göre belirlenmiştir. Yerel buğdaylar, genellikle ana merkezlerden uzakta ve yüksek bölgelerde bulunmuştur. Anket sonucunda, çiftçilerin tarlalarından toplam 1587 (1400

31 Zühre Aksoy, "Biodiversity and Biotechnology in the Agriculture Sector", Environmentalism in Turkey Between Democracy and Development? içinde, der. Fikret Adaman ve Murat Arsel (Aldershot, Hants; Burlington, VT: Ashgate, 2005), 235-249. 
başak numunesi ve 187 tohum numunesi) yerel buğday örneği toplanmıştır.

FAO'nun yayınladı̆̆ çalışmada, ${ }^{32}$

Yerel buğdaylar nerelerde üretilmektedir?

Yerel buğday üreticileri bu üretimi neden ve nasıl yapmaktadır?

Yerel buğday üretiminin sürdürülebilirliği in situ olarak nasıl sağlanabilir? sorularına cevaplar aranmış ve detaylı bir araştırma ortaya konmuştur. Araştırmada bulunan sonuçlara göre:

Yerel buğdayların hemen hemen Türkiye'nin birçok ilinde üretildiği gözlemlenmiştir. Yerel buğdayların en yaygın olarak ekildiği iller Ağrı, Ardahan ve Kars iken en az ekildiği iller Bartın, Çanakkale ve İzmir olmuştur.

Üreticilerin yerel buğday üretimine devam etmesini etkileyen birçok faktör gözlenmiştir. Bu faktörler pazara uzaklık, yükselti farkları, sosyo-ekonomik etkenler (incelenen hanenin yaş ortalaması, ekonomik durumu, kaç çocuğa sahip olduğu vb.), eğitim düzeyi, tarım arazilerinin durumu (sulu ya da susuz tarım) vb. olarak belirlenmiştir.

Üretimin in situ korunmasının; geleneksel üretim sürecinin korunması ve sürdürülebilmesi, insan ihtiyaçlarının ekosistem döngüsünde tekrar tanımlanması, insan sağlığına ve çevreye zarar vermeyen üretim biçiminin desteklenmesi ve, son olarak, halkın doğa ve çevre ile uyumlu yaşamasını sağlamak için halkı bilgilendirmek ve yeteneklerini geliştirmelerine izin vermek için faaliyet alanlarının yaratılması ile mümkün olduğu belirtilmiştir.

\section{Araştırma Bulguları}

\section{Çanakkale Ekolojik Yaşam Insiyatifi ve Bayramiç Yeniköy Grubu ${ }^{33}$}

Çanakkale Ekolojik Yaşam İnisiyatifi (ÇAYEK), gıdamızın kaynağıyla yeniden bağ kurmak, doğayla barışık yaşamlar kurgulamak ve ekolojik prensipleri yaşamın her alanına uyarlamak için buluşmuş bir grup Çanakkaleli; Çanakkale'de doğa dostu gıda üreticileri ve sağlıklı gıda talep eden şehirli alıcılarını buluşturmaktadır. Grup üyelerinden Elif Balçık grubu şu şekilde tanımlamaktadır:

Kasım 2012'den beri bir araya geliyor, birbirimizden öğreniyor, dayanışma ortamı yaratıyor, eğitimler düzenliyoruz. ÇAYEK kuruldu çünkü kentlerde giderek daha fazla doğadan uzaklaşıyoruz. Dünyanın neresinde, hangi koşullarda, kim tarafından üretildiğini bilmediğimiz gıdaların, genetiği ile oynanmış tohumların, doğaya zarar vererek ilaçlanmış sebze ve meyvelerin sağlığımıza zararlı ve sürdürülemez olduğunu düşünüyoruz. Çileğin ağaçta yetiştiğini, domatesin ketçap olduğunu zanneden çocuklar gördüğümüzde dehşete kapılıyor, kent ya-

32 FAO, Wheat Landraces in Farmers' Fields in Turkey: National Survey, Collection, and Conservation, 2009-2014, Mustafa Kan, Murat Küçükçongar, Mesut Keser, Alexey Morgounov, Hafiz Muminjanov, Fatih Özdemir, Calvin Qualset (Ankara, 2015).

33 Aslında Bayramiç Yeniköy grubu ve ÇAYEK grubu arasında birebir özdeşlik bulunmamaktadır. Ancak Bayramiç Yeniköy grubunun kurucusu Mustafa Alper Ülgen ÇAYEK grubunda da yer almaktadır. Bayramiç Yeniköy grubunun en aktif üreticisi Mustafa Bey olduğundan ÇAYEK grubundan genel olarak bahsetmenin faydalı olacağını düşündük. 
şamının ve endüstriyel üretim şeklinin bu çok uzak zannedilen geleceğe bizleri taşıdığını görüyor ve bir şeyler yapmamız gerektiğini düşünüyoruz. Bu gidişatı durdurabilmek için gıdanın en az mesafeyi kat etmesi, yerel tohumların korunması, ekolojik prensiplere göre üretim yapan bilinçli küçük çiftçileri kentli tüketicilerin desteklemesi, tüketicinin de üretimin bir parçası olmasına fırsat veren bir sisteme inanıyoruz. Gıdanın doğrudan üreticiden alıcıya ulaşmasının karşılıklı güven ve anlayışı besleyeceğini, toplumsal bağları güçlendireceğini, yalnızlaşan üreticilere cesaret vereceğini ve endişeli tüketicilere de çözüm olacağını düşünüyoruz. Hayalini kurduğumuz değişimin kendi yaşamlarımızdan başlaması gerektiğine inanıyoruz. Kaz Dağları'nın gerçek değerinin altın madeninde olmadığını, doğa ile uyumlu tarımsal üretimin asıl hazinemiz olduğunu biliyoruz. Bu hazineyi koruyabilmek için de ekolojik üretim yapan çiftçilerimizi tanımak ve desteklemek gerektiğini düşünüyoruz. Kaz Dağları'nda yaşanan doğa tahribatına karşı köylüleri güçlendirmek, kentlileri konunun sahibi yapmak, farkındalığı arttırmak için çalışmamız gerektiğini biliyoruz. Sağlıklı kalmak, doğanın bir parçası olduğumuzu unutmamak, parçası olduğumuz doğayı korumak ve gözetmek istiyoruz. ${ }^{34}$

ÇAYEK, Elif Balçık'ın da ifade ettiği doğrultuda, üreticilerle tüketicilerin bir araya geldiği toplantılar ve üretici çiftliklerine geziler düzenlemektedir. Sağlıklı gıda üzerine sohbetler yapmakta, doğaya uyumlu yaşamın temellerini atmaya yönelik eğitimler vermektedir. Doğaya saygılı olmayan kişi ve kurumlarla mücadele etmekte ve çevre konusunda çalışan diğer oluşumlarla birlikte hareket etmektedir. Son olarak, bilgi ve tecrübelerini benzer çalışmalar yapan birey ve gruplar ile paylaşmaktadır.

Bayramiç Yeniköy grubu ise permakültür felsefesini gözeterek tasarım yapan ve uygulayan, yerel tohumlarımıza sahip çıkarak, doğal tarım uygulamalar1 yapan, öğrendiklerini, ürettiklerini paylaşarak, kendi kendine yeten bir köy kurma girişimidir.

Üreticiler ve gönüllülerden oluşan Grup TaTuTa'ya ${ }^{35}$ bağlı üreticilerin birçoğu büyük kentlerden gelip sağlıklı ve ekolojik yaşam adına tarımsal üretime başlamıştır. Bu açıdan bakıldığında üretim, sosyal ve entelektüel faaliyet alanı olarak adlandırılabilir. Ancak üreticilerin birçoğu hayatlarını artık bu şekilde kazanmakta ve sürdürmektedir.

Gruptaki üreticiler birbirinden bağımsız bir şekilde üretim yapmakta, grubu daha çok sosyal faaliyet alanı olarak kullanmaktadır. Bu açıdan üretim faaliyetlerini grup üzerinden incelemek verilere ulaşma açısından zorluklar doğurmaktadır. Ancak grupta Bayramiç ilçesine bağlı Yeniköy'de Bayramiç Yeniköy grubunun kurucusu olan buğday üretici grubun yerel buğday üretimindeki

34 Görüşme 12 Kasım 2016 tarihinde yapılmıştır.

35 Buğday Ekolojik Yaşamı Destekleme Derneği tarafından yürütülen "Ekolojik Çiftliklerde Tarım Turizmi ve Gönüllü Bilgi, Tecrübe Takası" projesinin kısa adıdır. TaTuTa projesinin ana amacı Türkiye'de ekolojik tarımla geçinen çiftçi ailelerine mali, gönüllü işgücü ve/veya bilgi desteği sağlayarak ekolojik tarımı teşvik etmek ve sürdürülebilirliğini sağlamaktır. Detaylı bilgi için: http://www.bugday.org/portal/projeler.php?pid=41. 
hassasiyetini yansıtmakta ve üretim hakkında detaylı araştırma yapma şansı sunmaktadır.

\section{Yeniköy-Bayramiç Yerel Buğday Üretimi}

Yeniköy'de bulunan Mustafa Alper Ülgen 2011 yılında bir ekoköy projesi altında üretime başlamıştır. Temelinde yerel tohumlarla gıda üretimini benimseyerek üretime başlamış ve yerel buğday üretimini esas üretim biçimi haline gelmiştir. Üretici bölgeye uygun yerel buğdaylar ile üretim faaliyetine başlamış olsa da geçen yıllarda bu çeşitliliği arttırmıştır.

Çizelge 3 Üreticinin Yetiştirdiği Ürünler

\begin{tabular}{|c|c|c|}
\hline $395 \mathrm{da}$ & $1,5 \mathrm{da}$ & $2 \mathrm{da}$ \\
\hline $\begin{array}{l}\text { Kızılca, Sarı buğday, } \\
\text { Victor'un Sarı } \\
\text { buğdayı, Spelt, Siyez, } \\
\text { Senatorecappeli, } \\
\text { Emmer, Dersim, Zenon, } \\
\text { Karakılçık, Kamut, } \\
\text { Korasan, Akkunduz, } \\
\text { Rosetto, Kavlıca, } \\
\text { Şahman, Toros 1, Toros } 2\end{array}$ & $\begin{array}{l}6-7 \text { çeşit domates } \\
64 \text { çeşit yeşil biber } \\
\text { Soğan }\end{array}$ & 4 çeşit patates \\
\hline Yulaf, Çavdar & $\begin{array}{l}\text { Kavun, Karpuz, } \\
\text { Ayçiçeği, Kabak, Börülce, } \\
\text { Fasulye }\end{array}$ & Nohut \\
\hline
\end{tabular}

Çizelge 3'de görüldüğü üzere üreticinin yetiştirdiği buğdaylar ve diğer ürünler birçok farklı çeşitten oluşmaktadır. ${ }^{36}$ Üretici buğdayların bazılarını agroekolojik yöntemlere uygun şekilde ekerek bir biyoçeşitlilik alanı oluşturmuştur. Bu alan, tohumluk olarak elde az bulunan buğday çeşitlerinden oluşmaktadır. Az miktarda bulunan buğdayların çoğaltılması amaçlanmaktadır. $\mathrm{Bu}$ sayede bir dahaki ekim döneminde verim alınabilecek kadar tohum yetiştirilebilecektir.

Buğdaylar üretici tarafından el ile serpilerek atılmaktadır. 10-15 çeşit buğday birbirine karışmayacak şekilde araziye serpilir. Buğdayların birbirine karışmaması için baklagiller ile aralarına sınır oluşturulur. Bu baklagiller hem sınır görevi görürken hem de toprağa azot bağlayıcı özelliğinden dolayı buğdayların veriminin artmasını sağlar. Biyoçeşitlilik alanı dışında üretici diğer buğday ekim alanlarına traktör ile ekim yapılacak şekilde kavlıca ve kızılca buğdayı ekmektedir. Ekim alanı açısından asıl buğday yoğunluğunu oluşturan bu iki çeşittir.

36 Buğdayların yereldeki isimlerine ulaşamadıklarından dolayı bazılarını kendileri adlandırmaktadır: Toros 1, Toros 2 ve Victor'un sarı buğdayı vb. 
Ekimden önce ve sonra hiçbir kimyasal gübre ve ilaç kullanılmamaktadır. Bütün ürünler ekolojik yöntemlere uygun şekilde yetiştirilmekte ve sağlık aç1sından uygun gida üretimi yapılmaktadır. Buğday hasadından sonra uygulanan değirmen süreçleri de sağlıklı koşullarda yapılmaktadır. Hasat edilen buğdaylar su değirmeninde öğütülmekte bu sayede hiçbir endüstriyel süreçle karşılaşmamaktadır.

\section{Balıkesir Yaşam Dostu Ürün Dayanışma Grubu}

2012 Nisan ayında Balıkesir Barosu'nda buğday hakkında yapılan bir konferansta grubun buğday ve buğday ürünleri ile ilgili ilk hareketi başlamıştır. Konferanstan sonra barodaki avukatların yetmiş altı tanesinin katılımıla Yaşam Dostu Ürün Dayanışma Grubu kurulmuştur. Baroda daha önce başkanlık yapan şimdi ise grubun neredeyse bütün yükünü üstlenen Necdet Bayhan grubun kurucu üyesi olmuştur. Grup, yerel buğdaylar ile ekşi mayalı ekmek üretimini amaç edinmiştir. Ancak grup, ilk iki sene belli zorluklar ile karşılaşmıştır. Grup üyelerinin daha önce hiçbirinin tarımsal üretimde bir deneyimi bulunmadığından yerel buğday çeşitlerini bulmakta çok zorlanmışlardır. İlk iki sene sadece Cumhuriyet buğdayından ekmek üretilmiş, bununla beraber yerel buğdayları bulsalar bile ulusal piyasa içinde maddi değeri olmadığından, yerel

Şekil 1. 2015 yılı hasat edilen ve paketlenmiş yerel buğday çeşitleri

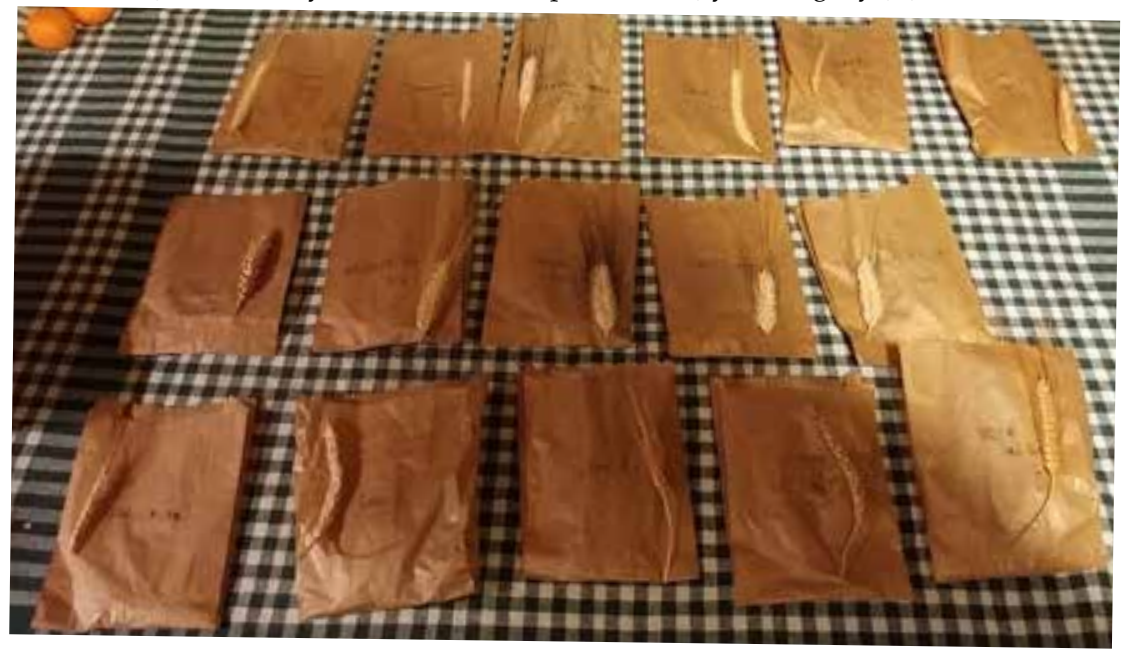

Üst sıra (soldan sağa doğru) Spelt, T. monococum, Senatorecapelli, Emmer buğdayı, Dersim buğdayı, Zenon. İkinci sıra Rosetta, Akkunduz, Korasan, Kamut, Karakılçık. Üçüncü sıra Kavlıca, Toros 2, Toros 1, Şahman, Victor'un buğdayı

Kaynak: Mesut Yüce Yıldız arşivi

buğday üreticilerinin söylediği fiyatları sorgulayamadan kabul etmek duru- 
munda kalmışlardır. Öyle ki bu sene köse buğdayını iki sene önceki fiyatından almışlar, yani daha önceki yıllarda çiftçilere daha yüksek fiyat ödemek zorunda kalmışlardır. Necdet Bayhan bu durumun düzeldiğini, artık kendilerinin de üretim yaptığını ve geçen dört yılda bir piyasanın oluştuğunu söylemektedir.

Grup, ekmek üretimine ilk olarak Balıkesir'in şehir merkezinde bulunan bir fırın ile anlaşarak başlamıştır. Ancak bu işbirliği bir yıl devam edebilmiştir. Bunun nedeni grubun anlaştığı fırın, normal şartlarda endüstriyel ekmek üretimi yapan bir fırındır. Fırıncı ürettiği endüstriyel ekmek miktarı arttıkça, yerel buğdaylar ile yapılan ekmeğin yapımı uzun ve zahmetli olduğundan, külfet gibi görmeye başlamış ve bir süre sonra yapmak istememiştir. Ancak bu grubun ekmek üretimini durdurmamıştır. 2013 yılında kendi fırınlarına geçerek ekmek üretimine devam edilmiştir. Bununla beraber ilerleyen yillarda grupta ayrılmalar ve sorumluluk almama durumları gözlenmiştir. Grup içi aidatlar ödenmemiş ya da yapılan toplantılarda sonuçlar çıkmamıştır. Bu yüzden Necdet Bayhan grubun isim olarak var olduğunu ancak iş yükünün, benim de gözlemleyebildiğim kadarı ile üç kişi tarafından üstlenildiğini belirtmiştir. Son iki yıldır toplantıların da yapılmadığı dile getirilmiştir. Fakat buna rağmen insanların bir şekilde gruptan kopmadığı tüketimde hala destek oldukları da ifade edilmiştir.

Grubun amacı, yerel buğdaylar ile sağlıklı buğday ürünleri üretebilmenin yanında tarımsal üretimde küçük üreticiye de alternatif yaratabilmektir. Tarımsal üretim içinde gittikçe yok olmakta olan küçük üreticiler bu sayede alternatif bir üretim biçimi bulmuşlardır. Necdet Bayhan yerel buğday üretimi üzerine oluşturdukları girişimin küçük çiftçiler tarafından iyi karşılandığını söyledi. Büyük üreticiler ile rekabet edemeyen, tohum, gübre ve kimyasal ilaç alamayacak küçük üreticiler zaten yerel buğday tiplerini ekmek durumunda kalmıştır. Fakat temelde üreticiler bunu kendi ihtiyaçlarını karşılamak için yapmışlardır. Grubun yerel buğday üretimi için maddi bir ilişki yaratması küçük üreticinin de üretime devam etmesini sağlamıştır. Necdet Bayhan'ın aktardığına göre en başlarda ekmeğin yapımında kullanmak için kara çavdar bulmakta çok zorlanılmıştır. Geçen zamanda kara çavdar ekenlerin sayısı on ila on beşe yükselmiştir. Bunun sadece Balıkesir'de grubun faaliyetleri ile arttığını söyleyebiliriz. Ancak piyasalarda çavdarın fiyatının etkileri de göz önüne alınmalıdır.

Necdet Bey grubun amacını dile getirirken özellikle iki konuyu vurguladı. Birincisi bu üretim faaliyetinin entelektüel alana sıkıştırılmasına karşı olduğunu dile getirdi. Bunu söylemesinin nedeni, son zamanlarda popüler olan şehirlerden kırsal alanlara gelerek tarımsal üretim yapan insanlar içindir. Buna elbette karşı değil, ama tarımsal üretimin zorluğu ve sürekliliği açısından zaten kırsal üretimde var olan insanların desteklenmesi gerektiği daha önemli bir yer tutmaktadır. Grup genelde tüketimi örgütlemek üzerinden işlemektedir. Bunun öncelikli sebebi Balıkesir'de yerel buğday üretimini devam ettiren üreticilerin varlığının hala olması söylenebilir. Ancak yerel buğdaylar ile ekmek üre- 
ten ve bunun sürdürülmesi için çaba harcayan kimse yoktur. Bu yüzden grup, üreticilerden ziyade tüketicilerin var olduğu ve ekmek üretimini esas alarak oluşturulmuş bir gruptur. Buğday üretiminin devamlılığı, üreticiler açısından somut, maddi ilişkiler ve güven ilişkisi üzerinden yürütülmektedir. Üreticilerden buğday alınırken endüstriyel buğday piyasasının oluşturduğu fiyatların \%20-30 fazlası ödenmektedir. Bu sayede üreticilerin yaptıkları üretimden gelir kazanmaları ve devamlılığı sağlanmaktadır.

\section{Ekmeğin Yapım Süreci}

Grupta yerel buğday üretimi yapan üreticiler var olmasına rağmen, grup dışında olan üreticilerden de yerel buğday çeşitleri tedarik edilmektedir. Bunun nedeni grupta var olan üretici sayısının azlığı ve ekmekte elde edilmek istenilen çeşitliliği grupta az sayıda var olan üreticilerden tedarik edilememesidir. Zaten bölgede var olan yerel buğday üreticilerinin ürünlerini satabileceği bir pazar sağlanarak üreticilerin üretime devam edeceği düşünülmektedir. Bu yüzden grup tüketim örgütlenmesinin esasıyla hareket etmektedir. Ekmeğin yapımında kullanılan buğday çeşitliliği de bu şekilde sağlanmaktadır.

Unun içeriğinde farklı yerel buğday çeşitlerinin kullanılması hem ekmeğin lezzeti açısından olumlu sonuç doğurmakta hem de farklı çeşitlerin bir arada kullanılarak tek tip ekmek üretiminin dışına çıkılması adına değerlidir. Ekmeğin yapımında unun büyük çoğunluğunu (\%50) yumuşak yapısından dolayı köse buğdayı oluşturmaktadır. Bunun dışında orta sert (Bezostaya ${ }^{37}$ ve sarı buğday) ve sert (karakılçık, kırmızı buğday ve Akakser) buğdaylar kullanılmaktadır. Buğday dışında ekmeğe \%10 civarında kara çavdar dahil edilmektedir. Unun yapımında köse buğdayının yoğunlukta olması unun yapısının daha ince olmasına olanak vermektedir. Sert buğdayların ve kara çavdarın ise lezzet katıcı özelliğinden yararlanılmaktadır. Üreticilerden alınan yerel buğdaylar tamamen kimyasal ilaç ve gübre kullanılmadan yetiştirilmektedir. Genel olarak buğday küçük üreticilerden, yani ortalama 30 dekar (da) arazisi olan ve bunun 15-20 dekarını buğday ile değerlendiren üreticilerden alınmaktadır. Grup, toplamda 20-25 üreticiden yerel buğday almaktadır. Ekmeğin yapım sürecine geçmeden önce ekmeğin yapımında kullanılan buğdayların genel özelliklerinden ve değirmene kadar olan sürecin nasıl geliştiğini anlatmakta fayda var.

Bölgede yerel çeşitlerden ekmeklik un yapımına uygun çeşit olarak köse buğdayın ekilmesi yumuşak dane yapılı olmasından kaynaklıdır. Bu yumuşak yapı buğdayın daha iyi ezilmesine ve daha ince bir un meydana getirmesine olanak verir. Ancak Balıkesir'in her bölgesinde köse buğdayı gibi yumuşak buğdaylar ekilmemektedir. Benim ziyaret ettiğim köylerden Kiraz köyünde yaygın olarak yerel çeşitlerden karakılçık çeşidi sert buğday ekilmektedir. Bunun ne-

37 Bezostaya aslında Rus kökenli buğday çeşididir. Ancak çok uzun zamandır Anadolu topraklarında da yetiştiğinden yerel buğday çeşidi olarak kabul edilebilir. 
deni Kiraz köyünde var olan ekolojik düzenin bozulmuş olmasıdır. Köylüler tarafından kurtların öldürülmüş ve sayılarının azaltılmış olması domuzların sayısını arttırmıştır. Sayısı artan domuzlar ise beslenmek için buğday tarlalarına gelmektedir. Fakat karakılçık gibi kılçıklı ve kavuzlu sert buğdaylar domuzlar tarafından pek tercih edilmemektedir. Karakılçık hem kılçıklarından dolayı yerken domuzların canını acıtmakta hem de danelerin başaktan dökülmesinin zor olması domuzlar tarafından tercih edilmemesine sebep olmaktadır. Köse gibi yumuşak buğdaylar ise domuzlar tarafından çok zarara uğramaktadır. Bu yüzden köse buğdayı genel olarak domuzların var olmadığı bölgelerde tercih edilmektedir. Diğer orta sertlikte ve sert buğdayların kullanımı ise agroekolojik yöntemlere uygun şekilde, var olan yerel çeşitlerin beraber kullanımı açısından uygunluk gözetilerek kullanılmaktadır. Bu sayede her buğdayın kendine özgü yapısal besin değerlerinden faydalanabilirken üretimde çeşitlilik sağlanmış olmaktadır.

Üreticilerin ektikleri yerel buğdaylar, orak gibi eski tarım aletleri veya biçerdöver ile hasat edilmektedir. Dane bakımından en verimli başaklar seçilecek şekilde tohumluk olarak ayırıldıktan sonra geri kalan buğdaylar hasat edilmektedir. En verimli buğday başaklarının seçilme sebebi bilimsel olarak doğal seleksiyonun işleme sürecine örnek gösterilebilir. Bir sonraki seneye tohumluk olarak kullanılacak buğdaylar, koşullar (iklimsel, toprak vs.) kötü gitmediği sürece ürün miktarı açısından verim artışı sağlayacaktır. Toplanan buğdaylar başaklarından, taşlardan ve çöpten ayrılmaları için çalkaya ${ }^{38}$ gönderilmektedir. Temizlenen buğdayların içlerinde ufak tefek de olsa kalan yabancı otlar, taşlar vb. el ile ayıklanmaktadır. Bu işlemden sonra unluk olanlar doğrudan değirmene götürülüp öğütülmeye hazırdır. Fakat bulgurluk olanlar önce suda kaynatılmakta daha sonra serilip kurumaya bırakılmakta en son olarak değirmene kırdırılmak üzere götürülmektedir.

Üreticilerden alınan yerel buğdaylar grup tarafından toparlanmakta ve İvrindi ilçesine bağlı Yağlılar köyünde bulunan değirmene getirilmektedir. Değirmen, taş değirmenin elektrik kullanılarak eskiden uygulanan işlemlerin aynısının uygulandığı modernleştirilmiş bir yapıdadır. Daha önceleri buğday öğütme işlemleri bölgede artık çalışmamakta olan su değirmenlerinde yapılmaktadır. Köye elektriğin gelmesiyle beraber su değirmenleri terkedilmiş ve kullanılmamaktadır. Grubun çalıştığı değirmenci daha önceleri su değirmeni işletmiş, köye 1976 yılında elektriğin gelmesi ile köy merkezinde elektrikli taş değirmenine geçmiştir. Değirmen, buğdayı bulgurluk ve unluk olarak iki gıda ürününe ayıran makinelerden oluşmaktadır. Bulgurluk olarak sert buğdaylar

38 Buğday temizleme makineleri yöresel farklılık göstermektedir. Çalka, Balıkesir'de kullanılan ismidir. Fakat diğer yerlerde farklı şekilde isimlendirilmektedir. Hem yöresel buğday işleme süreçlerinin hem de bazı adlandırılmaların farklı olmasından kaynaklı, buğdaydan ekmeğe geçen süreci incelediğimiz grubun bulunduğu yöreye göre ayrıca yazma gereksinimi duyduk. 
tercih edilir. Hem lezzet açısından hem de sert buğdayların un olarak kullanılması zor olduğundan böyle bir tercih yapılmaktadır. Tabii, lezzet yönünden geçmişten gelen kültürel alışkanlıkların da buna etkisi olduğu söylenebilir. Değirmen sahibi değirmenciliği maddi kazancından daha çok yerel buğdayların ekolojik değerinin kaybolmaması adına yapmaktadır. Asıl geçim kaynağını hayvancılık üzerinden sağlamaktadır. Kendisi de 50 da araziye köse buğdayı ekmektedir.

Un öğütmek için kullanılan taş değirmeni basitçe dizayn edilmiştir. Toplamda üç parçadan oluşmaktadır. Yukarıdan aşağıya, buğdayın içine döküldüğü kabza, silindirik öğütücü taşlar, taşların dönmesini sağlayan çarklar. Buğdaylar ilk olarak kabzaya dökülmektedir. Kabzaya dökülen buğdaylar huni benzeri bir yapı ile taşların ortasında bulunan yuvarlak açıklığa dökülecek şekilde, öğütülmesi için dönen taş silindirlere aktarılmaktadır. Öğütülen buğdaylar yine huni benzeri bir yapı ile çuvallara aktarılmaktadır.

Bulgurluk buğdaylar ise ilk olarak genişçe bir tahta kap içerisine alınarak az miktarda su ile beş dakika kadar karıştırılmaktadır. Bunun nedeni buğdayı biraz daha inceltmek ve var olan kabuğunun soyulmasını sağlamaktır. Buğday bu işlemden sonra kırma makinesine aktarılır. Kırma makinesi, buğdayı boylamasına kesen taş değirmene benzer daha küçük silindirik taşlardan oluşmaktadır. Taşların daha küçük olması buğdayın ufalanmamasını ve istenilen standarda uygun bir şekilde bulgur yapmasını sağlamaktadır. Buğday bulgura dönüştükten sonra çuvallara aktarılmaktadır. Alınan bulgurlar kabuğundan kaynaklı olarak kepekli yapıdadır. Kepeklerden kurtulmak için son bir işlem olarak bulgur rüzgârda serpilmektedir. Bu sayede kepeğin uçması ve sadece bulgur tanelerinin kalması sağlanmaktadır. Bundan sonra bulgur tüketicilere ulaştırılmaktadır. Çuvallara alınan unlar, ekmek yapılması için Kiraz köyüne götürülmektedir. Grubun gıda üretiminin büyük bir kısmı bu köyde yapılmaktadır. Bulgurluk buğdayların kaynatılması, ekmek ve tarhana üretimi vb. Kiraz köyünde grubun iş yükünün çoğunluğunu üstlenen Nazmiye Hanım tarafından yapılmaktadır. Buğdayın ve unun çoğunluğu Nazmiye Hanım’ın evinde depolanmaktadır. Nazmiye Hanım daha öncesinde zaten kendi geçimlerini sağlamak adına kendi gıda üretimini yapmaktadır. Gruba dahil olduktan sonra üretim, kendisi için ekonomik kazanç sağlayabildiği bir şekle dönüşmüştür. Nazmiye Hanım grubun bütün üretim ihtiyacını karşılamakta ve köyde bulunan diğer kadınları da bu sürece dahil etmektedir. İşler arttıkça, yalnız kendisi değil, köyde ki diğer yoksul kadınlar da üretim sürecine dahil olmuş ve maddi kazanç sağlamışlardır.

Ekmek yapımı ilk olarak kullanılan ekşi mayanın tekrar oluşturulması ile başlamaktadır. Var olan ekşi mayanın 1 kg'ı için $3 \mathrm{~kg}$ un ve $2 \mathrm{~kg}$ su ile karıştırılmaktadır. Karıştırma işlemi elektrikli bir karıştırıcı ile yapılmaktadır. İyice yumuşayıncaya kadar karışım karıştırıcı ile yoğrulmaktadır. Bu işlemden sonra mayanın büyüyüp gelişebilmesi için 12 saat beklemeye bırakılmaktadır. Bekle- 
tilen maya $6 \mathrm{~kg}$ un ve $3-4 \mathrm{~kg}$ su ile tekrar çoğaltılmaktadır. ${ }^{39}$ Bunun nedeni hem mayanın daha fazla yumuşamasını hem de bir sonraki ekmek yapımında bekletilecek mayanın tekrar tazelenmesini sağlamaktır. Bu işlemden sonra maya tekrar 12 saat bekletilmektedir. İkinci beklemeden sonra $4 \mathrm{~kg}$ maya, $25 \mathrm{~kg}$ un ile istenilen yumuşaklığa göre su eklenerek ekmek yapımına başlanmaktadır. Toplamda bu karışımdan 40 tane ekmek elde edilmektedir. Ekmekler şekil verildikten sonra şekillerinin bozulmaması ve konulduğu kaplara yapışmaması için içine nemlendirilmiş bez yerleştirilmiş sıralı tahta kaplara konulmaktadır. Taş fırına sürülmeden bu kaplarda bir saat daha bekletilmektedir.

Hazırlanan ekmek hamurları beklerken taş fırın kuru ağaç dalları ile yakılmaktadır. Fırındaki dallar yandıktan sonra işin en zor kısmı fırını temizlemek ve sıcaklığı düşürmek için silme işlemini gerçekleştirmektir. Fırındaki sıcaklığın çok yüksek olması ekmeklerin sadece dış kısmının pişmesine ya da ekmeğin tabanının yanmasına sebep oluşturabilir. Bununla beraber fırının iyice temizlenmemesi közlenmiş dal parçalarının ekmeğe yapışmasına neden olabilir. Firın uzun bir dala sarılı suya batırılan sslak bir bez ile iyice silinmektedir. $\mathrm{Bu}$ işlem her seferinde dallı bezi suya batırıp fırının içi silinecek şekilde 12-13 defa tekrarlanmaktadır. ${ }^{40}$ Silme işlemi, fırının sıcaklığı ekmeklerin pişebileceği ortalama 200 C dereceye düşene kadar devam etmektedir. Silme işlemi bittikten sonra ekmek hamurları fırına atılmaktadır. 30-45 dakika içinde ekmekler pişmiş ve satışa hazır hale gelmektedir.

\section{Kars Boğatepe Çevre ve Yaşam Derneği}

Boğatepe Çevre ve Yaşam Derneği 2002 yılında doğal ve toplumsal kaynaklar üzerinden köy yaşamını destekleme projeleri geliştirmek üzere kurulmuştur. Kırsaldaki yalnızlığın ve büyük kentlerin çekiciliğinin yarattığı göçü engellemek, yerel potansiyeller üzerinden toplumsal bilinç ve farkındalık yaratmak, geleneği sahiplenmek ve aidiyet duygularını geliştirmek amacıyla on yılı aşkın süredir faaliyetlerini sürdürmektedir. Bu kapsamda, yerel tohumların ekiminin yaygınlaştırılması; örtü altı yeşillik ve sebze yetiştiriciliğinin desteklenmesi; yenebilir, aromatik ve faydalı bitkilerin yetiştiriciliği, toplanması, kurutulması ve muhafazası ile kullanımı üzerine eğitimler düzenlenmiştir. "Dayanışmacı turizm" başlıklı kültürel tur gruplarının köylerde konaklamaları sağlamıştır. Kafkas Üniversitesi ile Kars kaşarının coğrafi işaretinin alınması; Birleşmiş Milletler Kalkınma Programı́nın desteği ile Ekomüze Zavot Peynircilik Müzesi'nin

39 Mayanın sürekli olarak kullanılmasını sağlamak için mikroorganizmanın yapısının canlı tutulması gerekmektedir. İkinci mayalama işlemi bekletilen sürede mayanın süresini uzatmakta ve taze kalmasını sağlamaktadır. Eğer gerekli zaman kaçırılırsa maya içinde bulunan mikroorganizmalar ölmekte ve maya kullanılamaz hale gelmektedir.

40 Aslında silme işlemi bu kadar tekrarlanmamalıdır. Fakat kullanılan fırının tavanının yüksek yapılmış olması fırının sıcaklığının düşmesini engellemekte, sıcak havanın içeride sıkışmasına neden olmaktadır. Bu yüzden sıcaklığı düşürmek zorlaşmaktadır. Grup, araştırma yapılan süreçte henüz inşa halinde olan yeni bir sıcaklık kontrolü ve göstergeli (termometreli) taş fırın yaptırmaktaydı. Yeni fırın sayesinde sıcaklıkta istenilen şekilde ayarlanabilecektir. 
kurulması gibi çalışmaları ve projeleri hayata geçirmiştir.

Dernek toplamda 470 üreticiden oluşmaktadır. Bu açıdan yerel üretim konusunda Türkiye açısından önemli bir paya sahiptir. Kars'ta derneğin yarattığ1 üretimin başarısını Tayfun Özkaya (2012) şöyle ifade ediyor:

Bu köyler 1800-2200 metre yükseklikteler. Kars'in ne kadar soğuk olduğunu biliyorsunuz. Sebze yetiştirmek zor. Çok yüksek köylerde nerede ise sadece hayvancılık yapılıyor. Biraz daha alçaktaki köylerde hayvancılık yanında buğday başta bazı ürünler de yetişebiliyor. Dernek çalışmalarına başlamadan önce çoğu köyde yazın dahi sebze yetişmiyordu. Daha çok tek yanlı beslenme nedeniyle başta kanser birçok hastalık kol gezmekte idi. Köylüler başta "buralarda sebze olmaz" demişler. Daha sonra her evin yakınında küçük bahçeler kurulmuş. Maydanoz, roka, tere, soğan vb. birçok yeşillik, ayrıca bazı sebzeler yetiştiriyorlar. Bazıları naylondan küçücük seralar yapmışlar. İlkbaharda evlerinin pencereleri içinde domates fidesi yetiştirip yazın bu seralara dikiyorlar. Biraz geç de olsa domates, biber vb. yetiştiriliyor. Bunlar sayesinde beslenme sistemi iyileşmiş. Yemek yediğimiz yerlerde hep bu bahçelerden yeşillik, sebze koparılıp yenildi. İlhan Bey "artık kanser olayları daha seyrek görülüyor" dedi. Her bölgenin üretebildiği kadar ürün çeşidi yetiştirmesinde büyük fayda var. Bunu "yerel üret, yerel tüket" şeklinde formüle edebiliriz. Kars'ta domates üretilebiliyorsa, başka yerlerde neler yapılmaz. Bu uygulamanın büyük yararları var. ${ }^{41}$

Diğer yandan derneğin en önemli başarısı yerel Kaplıca buğdayını yaygınlaştırmaktır. On yılı aşkın süredir yapılan yerel buğday ekimi, grubun neredeyse bütün üreticileri tarafından yapılmaktadır. Yerel buğday üretimine Kaplıca ${ }^{42}$ buğdayının yaygınlaştırılması ile başlanması üretim açısından yerel buğday ekiminin kabullenilmesi açısından doğru bir adım olduğunu göstermektedir. Bölgede yoğun şekilde büyükbaş hayvancılık da yapıldığından, Kaplıca buğdayında bulunan kepek, hayvan yemi ihtiyacını karşılayabilmektedir. Tayfun Özkaya Kaplıca buğdayının önemine aynı yazısında şöyle devam ediyor:

İkinci konu da yerel buğdaylar. Bunlardan en önemlilerinden biri de kavılca denilen yerel buğday çeşidi. Bildiğimiz gibi Türkiye buğdayın ana vatanı. Kavılca antik bir buğday. Bu proje olmasaydı muhtemelen kaybolurdu. Köylerde bunu üretenlerle konuştuk. Beş-altı sene evvel buğdayı kimyasal gübre ile üretiyorlardı. Bazıları tohuma da para veriyordu. Şimdi sadece hayvan gübresi kullanıyorlar. Tohum da artık kendilerinden. Verim Kavılcada ve kırmızı buğdayda önceye göre kısmen artmış. Masraflar azalınca gelirleri de önceye göre artmış bulunuyor. Kavılca buğdayı daha pahalı satılıyor. Köylüler bize kırmızı buğday çeşidi 60 kuruşa satılırken Kavılcanın 3-4 TL'ye bile satıldı̆̆ını söylediler. Yerel çeşitlerin besin maddeleri açısından zengin olduğunu araştırmalardan biliyoruz. Kavılcada olduğu gibi çoğunda lezzet de çok iyi oluyor. ${ }^{43}$

41 Tayfun Özkaya, "Kars'ta Güzel Şeyler Oluyor", http://www.yurtgazetesi.com.tr/karstaguzel-seyler-oluyor-makale,2809.html, erişim tarihi 16 Kasım 2016.

42 Mirza Gökgöl Türkiye Buğdayları kitabının ikinci cildinde buğdayın ismini Kaplıca olarak vermiştir, bkz. Gökgöl, Türkiye Buğdayları. Ancak Kavlıca ve Kavılca kullanımları da yaygındır. Bu çalışmada üçünü de kullandık.

43 Özkaya, "Kars'ta Güzel Şeyler Oluyor”. 
Dernek üretim konusunda ciddi bir başarıya zaten ulaşmış durumdadır. Tayfun Özkaya'nın da belirttiği üzere her evin kendine ait bir bahçesi bulunmaktadır. Bunun dışında Kaplıca buğdayı üretimi bölgenin neredeyse her tarafında yaygındır. Dernek; Çakmak, Boğatepe, Boğazköy, Alçılı, Keçili, İncesu, Yolboyu, Kuyucuk, Akdere, Dikme, Cumhuriyet, Hacı Arif, Çetindurak, Arslanoğlu, Gülyüzü, Davulköy, Gelirli, Çamurlu, Burcalı, Küçük Boğatepe, Akçakale ve Çamçavuş olmak üzere 23 köyde Kaplıca üretimini gerçekleştirmiştir. Köylerdeki üretici sayısı da gün geçtikçe artmaktadır. Bütün bu projenin en başından beri yürütücüsü ve derneğin kurucusu olan İlhan Koçulu, Kaplıca buğdayı üretimini arttırmayı hedeflerken ellerinde çok az sayıda tohum olduğunu söyledi. Ancak üreticilerle kurulan birebir ilişkiler ile geçen on dört yılda Kaplıca üretimi bütün bölgeye yayılmış ve kendi yerel piyasasını geniş ölçüde oluşturmayı başarmıştır. Bu başarı sadece Kaplıca'nın bölgedeki iklimsel koşullara rağmen oluşan yüksek verimi veya hayvansal üretime sağladığı katkıdan dolayı değildir. Sağlıklı buğday ürünlerine artan talep sonucunda Derneğin üreticiler ve tüketiciler arasında köprü vazifesi görmesinin de etkisi vardır. Üreticiler için, buğdaylarını satabilecekleri geniş bir pazar mevcuttur. En başta ekonomik başlayan ilişki sonrasında sosyal ve ekolojik bilinci de beraberinde getirmiş ve sürdürülebilirliğini sağlamıştır.

\section{Üreticilere Ait Bilgiler ve Üreticilerin Yerel Üretim Hakkında Görrüşleri}

Üreticiler ile yapılan görüşmelerde birçok ürün hakkında bilgi toplanmıştır. Bu bilgiler ışı̆̆ında oluşan üretim şekli, birçok çeşidin bir arada ekildiği beraberinde hayvancılığın da yapıldığı yerel üretim ve tüketim açısından son derece başarılı bir durumdadır. Görüşülen üreticilerin hepsi birbirinden farklı rakımda köylerdedir. Bu sayede Kaplıca buğdayının verim açısından yüksekliklere göre değişimi de gözlenebilmektedir.

Görüşülen üreticilerden ilki Kars'ın Susuz ilçesine bağlı İncesu köyüne bağlıdır. ${ }^{44} 68$ yaşında ortaokul mezunu olup, eşi ve bir erkek çocuğuyla beraber yaşamaktadır. Görüşülen üretici 200 dekarlık bir araziye sahiptir. Bu alanda Kaplıca buğdayı, kırmızı buğday, hayvan yemi olarak kullanmak için fiğ ve korunga ekmektedir. Bunun yanında arıcılık da yapmakta ve kendi tüketimini karşılayabileceği şekilde küçük bir serası bulunmaktadır. Bu serada mısır, domates, biber, lahana, fasulye, soğan vb. ürünler ekmektedir. Ayrıca büyükbaş hayvancılıkla da uğraşmaktadır.

İncesu üreticisi her sene bütün alanı ekmediğini söylemektedir. Genelde 3540 dekar arası buğday ekmektedir. Bu ekimin 10 dekarı kırmızı buğday olup geri kalanı Kaplıca buğdayıdır. Yapılan ekimde hiçbir şekilde kimyasal gübre

44 Görüşme 14 Ekim 2016 tarihinde yapılmıştır. 
ve ilaç kullanılmamaktadır. Bunun nedeni üretici açısından aşağıdaki şekilde siralanmaktadir.

Maddi açıdan kimyasal ilaçları ve gübreleri karşılayabilecek bir kazancı olmadığını bunun dışında sağlık açısından da kendisini olumsuz etkileyeceğinden daha sonra hastanelere para yatırmak istemediğini söylemektedir. Yerel ve organik yetiştirmenin kazancının kendine yettiğini ve maddi getirisinin iyi olduğunu söylemektedir. Katkı maddesi olmadan üretilen gıdaların tadının bile farklı olduğunu bu şekilde beslenmenin her açıdan daha iyi olduğunu söylemektedir.

İncesu üreticisi kırmızı buğdaydan hiçbir hayvansal gübre dahi kullanmadan bir dekara 150-200 kg verim alabildiğini söylemektedir. Kaplıca buğdayında ise bu verimin arttığını 250-300 kg arası değiştiğini söylemektedir. Kaplıca buğdayından elde edilen verim daha patoza ${ }^{45}$ girmiş haliyle, yani saman olarak oluşan otlardan ayrı olarak hesaplanmaktadır. Ancak buğday hasadında elde edilen hiçbir ürün boşa gitmemektedir. Bunun Kars'ın genelinde bütün yerel üreticiler için büyük bir avantaj olduğunu söylenebilir.

İncesu üreticisi, buğday dışında tamamen doğal şekilde bal, tereyağı ve peynir üretimi de yapmaktadır. Toplamda 20 kovanı bulunan üretici, kovan başı yedi kg bal almaktadır. Endüstriyel arıcılığa göre düşük bir üretim miktarı olsa da doğal yöntemler ile yapmaktan ve şeker kullanım maliyeti ödemediğinden memnun olduğunu ifade etmektedir. Balı piyasa fiyatının üstünde bir fiyatla satarak bu açığı kapattığını söylemektedir. Balın kilosunu 65 TL civarında satmaktadır. Devletin de arıcılığa kovan başı 5 TL desteği olmaktadır. Büyükbaş hayvan sayısının yıldan yıla değiştiğini ancak genelde 8 büyükbaş hayvanı bulunduğunu söylemektedir. Bu büyükbaşlardan tereyağı ve Malakan ${ }^{46}$ peyniri üretmektedir. Tereyağın kilosunu 30 TL üzerinde satmaktadır.

Görüşülen diğer yerel buğday üreticimiz Hacı Arif köyündendir. ${ }^{47} 67$ yaşında olup, eşi, çocukları ve torunlarıyla birlikte yedi kişilik bir ailedir. Üretici hayvancılık ile yaklaşık 200 dekar buğday üretimi yapmaktadır. Ektiği buğdaylar, kırmızı buğday, Topbaş, Kaplıca ve beyaz buğdaydır. Bunun dışında arpa, yulaf, fiğ ve korunga da ekmektedir. Bu üretici de benzer şekilde ticari buğday çeşitlerinin masraflarını karşılayamadığından dolayı yerel buğday ektiğini söylemektedir. Kırmızı buğdayı sadece kendilerine ekmek üretecek kadar ekmekte yoğun olarak Kaplica ekmektedir.

Üretici Kaplıcanın çok kıymetli olmasının nedenini saman veriminin çok yüksek olmasından kaynaklandığını ifade etmektedir. Kaplıca buğdayından ortalama bir dekara $150 \mathrm{~kg}$ verim almaktadır.

45 Hasat edildikten sonra ilk ayıklama işleminin yapıldığı makine. Samanlar patoz işlemi sonrası oluşur.

46 Kars ve çevresinde geçmiş yıllarda yaşayan Rusya göçmenleri. Bu göçmenler Kars bölgesinde şu an çok az sayıdadır.

47 Görüşme 15 Ekim 2016 tarihinde yapılmıştır. 
Kuyucuk üreticisi Kaplıca buğdayı, kırmızı buğday ve diğer üreticilerden farklı olarak çoğunlukta Kırik buğdayı ekmektedir. Bu üretici, hayvancılık ile daha kısıtlı uğraşmakta buğdayı kendi ekmek ihtiyaçları için de üretmekte ve bu nedenle Kırik buğdayı ekmektedir. Ancak bu sene fazla yağışlardan buğdayın verimi düşük olmuş ve üreticiyi zora sokmuştur. Buğdayda sürme ${ }^{48}$ gözlenmiş ve verimlerin düşük olmasına neden olmuştur. Ancak bundan önceki yıllarda ortalama 80 dekar Kırik buğdayı eken üretici bir dekar alandan 100 kg gibi bir verim almaktadır. Yerel buğday üretimi neden yaptığını şu sözlerle ifade etmektedir: "Endüstriyel tohumların hiçbirini tanımıyorum. En iyi tohum kendi bildiğimiz, üretimini bildiğimiz tohumdur."

Dernek içindeki üreticilerin neredeyse hepsi Kaplıca ve kırmızı buğday üretimi yapmaktadır. Kaplıca buğdayı daha çok bulgurluk olarak kullanılırken, kırmızı buğday unluk olarak tercih edilmektedir. Ancak Kaplıca buğdayına unluk olarak oluşan talepten dolayı Kaplıca buğdayı da unluk olarak değerlendirmek üzere öğütülmeye başlanmıştır.

Yerel buğdayların bölgede yoğun olarak var olması, yerel buğday işlemlerinin daha endüstriyel bir şekilde gelişmesine olanak sağlamıştır. Yani diğer gruplardan farklı olarak Kars'ta buğday üretim ve işleme süreçleri teknolojinin daha yoğun olarak kullanıldığı bir durumdadır. Üretimin çokluğunun ve piyasanın bu üretimi karşılayacak tüketim hacminin olması bunun en önemli etkenlerindendir.

Yerel buğdaylar genelde 150 dekar civarındaki büyüklükteki arazilerde yetiştirilmektedir. Bir önceki ekimden elde edilen buğdaylar, toprağa ekilmeden önce hiçbir türlü kimyasal gübre veya herbisit kullanılmadan, sadece toprak tırmıkla sürüldükten ve yabancı otlar toprağa karıştırıldıktan sonra ekilmektedir. $\mathrm{Bu}$ aynı zamanda toprağı daha verimli hale de getirmektedir. Buğdaylar ekildikten sonra ise yine hiçbir kimyasal işlem uygulanmamaktadır. Yabancı otlar ile buğdayların beraber büyümesine izin verilmektedir. Hatta hasat sırasında buğday ile birlikte yabancı otlar da bu hesaba katılmaktadır. Çünkü bu yabancı otlar hayvancılık açısından değerlidir. Saman ve hayvan yemi olarak kullanılmaktadır. Ancak buğdayın daha sonra değirmende işlem görebilmesi için patoz makinesi ile daneler ve saman olarak kullanılan otları birbirinden ayrılmaktadır. Ayrılan buğdaylar çuvallara doldurularak değirmene götürülmektedir.

Bölgede su değirmeni ve elektrikli taş değirmeni olmak üzere iki tip değirmen vardır. Su değirmeni sadece Arpaçay'da faaliyet göstermektedir. Hem ulaşım açısından hem de su değirmenlerinin buğday işleme hızı daha yavaş olduğundan üretim hacmi yüksek olan üreticiler tarafından çok tercih edilmemektedir. Ancak su değirmeninin oluşturduğu un kalitesinin daha ince ve iyi

48 Buğdayın kül gibi siyah bir renge dönüşerek kullanılamaz hale gelmesidir. Sürme denmesinin sebebi ise bölgede yaşayan kadınların bu buğdayları makyaj malzemesi olarak kullanmalarıdır. 
olduğu söylenebilir. Elektrikli taş değirmeninde buğdaylar unluk ve bulgurluk olarak iki farklı makine tarafından öğütülmektedir. Buğdayların bulgura çevirim işlemi unluğa çeviriminden görece daha basittir. Buğday çuvalları geniş bir huniye dökülür. Bu huni neredeyse 50-60 kg buğdayı tek seferde alabilmektedir. Buradan huninin makineye bağlı kısmında var olan delikten silindirlerin sürekli çevirdiği bantlara bağlı kefelerce kırma işlemini yapan taşlara buğdayları aktaran hazneye taşınmaktadır. Bu hazneden taşlara aktarılan buğdaylar kırılmakta ve daha sonra alt alta dizilmiş üç kademeli geniş yatay süzgeçlere aktarılmaktadır. İlk ve en üstteki kaplıca buğdayının kabuklarını tutmaktadır. Kabukların geçemediği büyüklükteki deliklerden bulgur olarak istenilen ana ürün geçmektedir. Son olarak en altta bulunan üçüncü alana ise un inceliğinde olan buğday ruşeymi aktarılmaktadır. Bu öğütme sürecinden sonra ayrılan kabuklar dahil bulgur ve rüşeym ayrı çuvallara doldurulmaktadır. Kabuklar hayvan yemi olarak kullanılmaktadır. Ruşeym ise çok az bir miktarda çıksa da (üç tona $30 \mathrm{~kg}$ gibi) buğdayın en değerli ürünüdür.

Un elde etme işlemi ise daha kompleks bir süreçtir. Genel olarak un elde etmek için bölgede yerel buğdaylardan kırmızı ve Kırik buğdayı kullanılmaktadır. Ancak daha öncede belirttiğim gibi Kaplıca buğdayına doğan ilgiden dolayı, bu buğdayın da ununun üretilmesine başlanmıştır. Kaplıca buğdayının genelde un olarak şimdiye kadar tercih edilmemesinin sebebi ise kabuklu ve sert yapısından dolayı işleme sürecinin kırmızı ve Kırik buğdayına göre daha zahmetli olmasından kaynaklanmaktadır.

Un, buğdayların birkaç makinenin birleşiminden oluşan bir süreçten geçtikten sonra elde edilmektedir. Buğdaylar ilk olarak selektöre ait hazneye doldurulmaktadır. Buğdaylar aynı bulgurluk buğdaylar için uygulanan süreç gibi bantlara bağlı keseler ile yukarı taşınmakta ve makinenin süzgecine aktarılmaktadır. Burada buğdaylar, taşlar ve yabancı otlardan ayıklanmaktadır. Temizlenen buğdaylar makineler arası aktarımı sağlayan borular ile selektörden yıkama ünitesine aktarılmaktadır. Yıkama ünitesi buğdayların hem yumuşamasını hem de kalan toprak ve tozdan ayıklanmasını sağlamaktadır. Buğdaylar yıkandıktan sonra beklemesi için büyük haznelere aktarılmaktadır. Bu haznelerde buğdaylar tam olarak üç saat dinlendirilmektedir. Bunun nedeni, buğdaylarda temizlenme ve yıkanma esnasında oluşan isıl sürecinin normal koşullara getirilmesinin istenmesidir. Buğdaylar üç saatlik bekleme sürecinden sonra kabuklarının soyulması için kabuk soyucuya aktarılmaktadır. Kabuklar soyulduktan sonra ise taş değirmenine aktarılarak öğütülme işlemi gerçekleşmektedir. Öğütülen buğdaylar un ve kepek olarak ayrışarak farklı borular ile son haznelere aktarılmakta ve bu haznelerden kepekte, unda ayrı çuvallara doldurulmaktadir.

Kars Boğatepe Çevre ve Yasam Derneği üretimde sürdürülebilirliği tam anlamıyla gerçekleştirmiş ve üretim ve tüketimde kolektivizasyonu sağlayarak piyasanın baskısını büyük ölçüde kırmayı başarmıştır. Kendi üretim ve tüke- 
tim alanlarını oluşturmayı başaran üreticiler hem sağlıklı üretim hem de sağlıklı tüketim başarısı ile hayat koşullarını oluşturmuştur. Endüstriyel üretimde oluşan yabancılaşmanın önüne geçmişlerdir.

\section{Gruplar, Dernekler ve Endüstriyel Üretim Sürecinin Ortak Değerlendirmesi}

Çanakkale grubu üretimde teknolojik ve bilişsel başarıyı sağlamıştır. Bunun yanında agroekolojik yöntemlere uygun yerel buğday biyoçeşitliliğini ön plana alan bir üretim gerçekleştirmektedir. Ancak üretimi ortaklaştırabileceği bir yapıya sahip değildir. Balıkesir grubu ekmek üretiminde buğday çeşitlililiğini sağlayabilmiş, tüketim alanına yönelik kolektivizasyonu sağlamış ve buna bölgede var olan üreticileri dahil etmiştir. Ancak üreticiler gruptan bağımsız hareket etmektedir. Bu grubun tüketimde örgütlenmeyi esas alarak var olan yerel buğday üreticilerinin üretime devam edeceğini düşüncesinden ileri gelmektedir. Kars grubu ise bu koşulların hepsini bir araya getirmiş ve üretim ve tüketim alanını sosyal, teknolojik ve ekonomik olarak örgütlemeyi başarmıştır.

Gruplar ve dernekler incelenirken verilen maliyet ve verim hesapları birbirinden bağımsız gibi duran veriler oluşturmaktadır. Grupların her birine ait ortak bir maliyet tablosu çıkarılamamasının sebebi derneklerin üreticilerinin ektiği buğdayların maliyetlerinin, verimlerinin, üretim koşullarının vb. farklı ve karışık olmasından kaynaklıdır. Bu bölümde kabaca bölgelere göre endüstriyel buğday verileri ile grupların verileri kıyaslanmaya çalışılmıştır.

Çanakkale grubu yerel buğday üreticisi, bir çok farklı buğday çeşitleri ekmekte ve farklı verimler almaktadır. Ancak yerel buğdaylardan ortalama 200 $\mathrm{kg} /$ da verim aldığı söylenebilir. Balıkesir grubunda var olan üreticiler ve Balıkesir grubunun buğday aldığı üreticilerin verimleri ise buğday çeşidine ve bölgeye göre değişmektedir. Özellikle unluk olarak kullanılan Köse buğdayından ortalama $250 \mathrm{~kg} /$ da verim alınmaktadır. Ancak 350-400 kg/da civarında verim alınan bölgeler de mevcuttur. Bunun yanında Bezostaya, Karakılçık vb. buğdaylardan ortalama $200 \mathrm{~kg} /$ da gibi verim alınmaktadır. Kars bölgesinde ise Kavılca buğdayı ortalama $250 \mathrm{~kg} /$ da verim vermekte, rakıma göre bazı bölgelerde 400 $\mathrm{kg} /$ da dolayında verim verebilmektedir. Bu verimleri endüstriyel buğday çeşitlerinin verimleri ile kıyaslayacak olursak bu bölgelerde aslında yerel buğday verimleri ile aralarında ciddi farklar olmadığını hatta yerel buğdayların bazı bölgelerdeki ve özellikle Kars'ta var olan başarısının nedeni daha net anlaşılmaktadır (Çizelge 4). 
Çizelge 4 Kars, Balıkesir ve Çanakkale İllerinin 2014-2016 Yılları Arası Endüstriyel Buğday Verimleri

\begin{tabular}{|c|c|c|c|c|}
\hline \multirow{2}{*}{ Y1l } & İller & Ekilen Alan (da) & Üretim (ton) & Verim (kg/da) \\
\hline \multirow{3}{*}{2014} & Kars & 656504 & 84039 & 128 \\
& Balıkesir & 1187644 & 316069 & 266 \\
& Çanakkale & 807603 & 266445 & 330 \\
\hline \multirow{3}{*}{2015} & Kars & 578190 & 94801 & 164 \\
& Balıkesir & 1173764 & 281718 & 241 \\
& Çanakkale & 792741 & 258508 & 326 \\
\hline \multirow{3}{*}{2016} & Kars & 467890 & 63684 & 136 \\
& Balıkesir & 1222206 & 365533 & 315 \\
& Çanakkale & 789090 & 248475 & 299 \\
\hline
\end{tabular}

Kaynak: TÜİK, 2016. Buğday İstatistikleri, http://tuikapp.tuik.gov.tr/

Çizelge 4'te yer alan verilere göre endüstriyel buğday verimliliğinin az olduğu bölgede yerel buğday çeşitlerine olan ilginin daha fazla olduğu sonucunu çıkarabilmekteyiz. Bunun yanında endüstriyel buğdaylar ve yerel buğdayları birim fiyatları üstünden kıyaslayacak olursak yerel buğdayların satış fiyatlarının daha yüksek olduğunu görmekteyiz (Çizelge 5).

Çizelge 52016 Yılı Kars, Balıkesir ve Çanakkale İllerinin Buğday Fiyatlarının Karşılaştırilmas1

\begin{tabular}{|c|c|c|c|c|}
\hline Y1l & İller & $\begin{array}{c}\text { Endüstriyel } \\
\text { Buğday Fiyatları } \\
(\mathrm{kg} / \mathrm{TL})\end{array}$ & $\begin{array}{l}\text { Yerel Buğday } \\
\text { Çeşitleri }\end{array}$ & $\begin{array}{c}\text { Fiyat (kg/ } \\
\text { TL) }\end{array}$ \\
\hline \multirow{3}{*}{2016} & Kars & 0.75 & $\begin{array}{l}\text { Kavlıca } \\
\text { Kırmızı } \\
\text { Buğday }\end{array}$ & $\begin{array}{l}0,60 \\
3,50\end{array}$ \\
\hline & Balıkesir & 0,80 & $\begin{array}{c}\text { Köse } \\
\text { Karakılçık }\end{array}$ & $\begin{array}{l}1,25 \\
1,75\end{array}$ \\
\hline & Çanakkale & 0,82 & $\begin{array}{l}\text { Kavlica } \\
\text { Kizilca }\end{array}$ & $\begin{array}{l}7,00 \\
6,50\end{array}$ \\
\hline
\end{tabular}

Kaynak: TÜİK, 2016. Buğday İstatistikleri, http://tuikapp.tuik.gov.tr/ ve doğrudan görüşmeler; 2016

Yerel buğday üretimi, endüstriyel buğday çeşitleri ile aynı koşullarda kim- 
yasal girdi kullanımının olmamasına bağlı olarak daha düşük üretim maliyeti oluşturmaktadır. İncelenen bölgelerde yerel ve endüstriyel ürünlerde verim farkının çok düşük olması yerel buğdayların üreticisi açısından mantıklı bir seçim olduğunu göstermektedir. İncelenen bölgelerde endüstriyel tarımın Türkiye geneline oranla az yapılıyor olmasından dolayı bölgelerdeki endüstriyel buğday maliyet verilerine ulaşılamamıştır. Ancak endüstriyel buğday tarımının yarattığ1 maliyetin Türkiye genelinde benzer olduğu düşünülmektedir. Bunun nedeni kimyasal ilaç, gübre vb. yoğun işletme dışı girdi kullanılması ve tohum ve kimyasal girdilerde belli şirketlerin hâkim olması, yüksek oranda dışa bağımlılık ve fiyatlarının piyasada çiftçi aleyhine yüksek belirlenmesi ile hızla fiyatlarının artmasıdır. Bu yüzden İzmir ili ölçeğinde endüstriyel buğdayın maliyeti üzerinden karşılaştırma yapılmıştır (Çizelge 6).

Çizelge 6 İzmir İli Endüstriyel Buğday Üretimi İle İncelediğimiz Gruplardaki Yerel Buğday Üretiminde Bazı Maliyet Unsurlarının Karşılaştırılması

\begin{tabular}{|c|c|c|}
\hline Girdiler & $\begin{array}{c}\text { Endüstriyel Buğday } \\
\text { Maliyeti (TL/da) }\end{array}$ & $\begin{array}{c}\text { Yerel Buğday maliyeti } \\
\text { (TL/da) }\end{array}$ \\
\hline Gübre Bedeli & 42,00 & 5,75 \\
\hline Tohum bedeli & 25,00 & 30,00 \\
\hline Kimyasal ilaç bedeli & 17,50 & - \\
\hline Su bedeli & 25,00 & $\mathbf{5 , 7 5}$ \\
\hline TOPLAM & $\mathbf{1 0 9 , 5 0}$ & $\mathbf{2 0 1 6}$ \\
\hline
\end{tabular}

Kaynak: İzmir İl Gıda Tarım ve Hayvancılık Müdürlüğü, 2016

Yerel buğdayların üretim maliyetleri Çizelge 6'da görüldüğü gibi oldukça düşüktür. Leonardit ${ }^{49}$ kullanan gruplarda sadece ekstra bir maliyet bulunmakta ancak gruplardaki yerel buğday üreticilerinin birçoğu Leonardit veya diğer dış girdileri kullanmamaktadır. Ayrıca incelenen gruplarda yerel buğday üreticileri üretimi kuru arazilerde yaptıklarından dolayı sulama masrafı da oluşmamaktadır. Bunun dışında grupların yerel buğday üretim biçimine göre işçilik masrafları da daha düşüktür (Çizelge 7).

49 Üreticilerin kullandığı leonardit aslında yüksek oranda hümik asitler dışında; karbon, makro ve mikro besin elementleri içeren, kömür düzeyine ulaşmamış tamamen doğal organik madde olarak da tanımlanır. Yani topraktan mineral madde alınımını arttırmak için kullanılan uzun vadede etki eden bir yapıdadır. 
Çizelge 7 İzmir İli Endüstriyel Buğday Üretimi İle İncelediğimiz Gruplardaki Yerel Buğday Üretiminde İşçilik Masraflarının Karşılaştırılması

\begin{tabular}{|c|c|c|}
\hline İşçilik Giderleri & $\begin{array}{c}\text { Endüstriyel Buğday } \\
\text { Maliyeti (TL/da) }\end{array}$ & $\begin{array}{c}\text { Yerel Buğday Maliyeti } \\
\text { (TL/da) }\end{array}$ \\
\hline İlk sürme (Anız bozma) & 35,00 & 35,00 \\
\hline Diskaro & 25,00 & 25,00 \\
\hline Tirmık çekme & 20,00 & 20,00 \\
\hline Gübreleme işçiliği & 17,50 & - \\
\hline Ekim & 15,00 & 15,00 \\
\hline Sürgü & 15,00 & 15,00 \\
\hline Zirai mücadele işçiliği & 14,00 & - \\
\hline Sulama işçiliği & 17,00 & - \\
\hline Hasat-Harman & 25,00 & 25,00 \\
\hline Balya yapma (makine) & 30,00 & 30,00 \\
\hline TOPLAM & 213,5 & 140 \\
\hline
\end{tabular}

Kaynak: İzmir İl Gıda Tarım ve Hayvancılık Müdürlüğü, 2016

Çizelge 7'de endüstriyel buğday üretiminde işçiliğinin yarattığ maliyetin yerel buğday üretim maliyetleri ile benzer süreçler göz önüne alınarak İzmir ili örneğinde karşılaştırılması yapılmıştır. Aslında yerel buğday üreticileri küçük ölçekli olduğundan hemen hemen hepsi kendi işçiliklerini kendileri gerçekleştirmektedir. Yani tabloda gözüken işgücü unsurlarının çoğu aile çalışanları tarafından gerçekleşmekte ve itibari olarak ailenin işgücü gelirlerini oluşturmaktadır. Ancak aynı süreç küçük ölçekli endüstriyel buğday üretimi yapan üreticiler için de geçerlidir. Yukarıdaki çizelgede benzer işçilik maliyetleri kıyaslandığında vurgulanmak istenen, yerel buğday üretiminde gübreleme, zirai mücadele ve sulama maliyetinin oluşmadığıdır.

Bunlar dışında endüstriyel buğday ve yerel buğday maliyetlerini nakliye biçimi açısından farklılık göstermektedir. Endüstriyel buğdayların nakliyesinin ambara taşıma süreci genel olarak çiftçiler tarafından üstlenilirken, pazara taşıma bedeli araya giren komisyoncu ya da buğdayı alan kurum tarafından üstlenilmektedir (Çizelge 8). Yerel buğday gruplarında ise ambara taşıma, değirmene götürme daha sonra da pazara ulaştırma süreci vb. giderler üretici 
tarafından karşılanmaktadır. Burada vurgulanması gereken nokta endüstriyel buğday üretiminde üretici buğdayı ürettikten sonra buğdayını doğrudan elden çıkarmaktadır. Ancak yerel buğday üretiminde üretici ekmek ya da bulgur olarak pazara kadar geçen bütün süreçte var olmaktadır. Yani kısacası yerel buğday grupları genel anlamda küçük işletmeler olduğundan taşıdıkları miktarlar da küçüktür. Bu yüzden nakliye maliyetleri daha yüksek olmaktadır. Örnek olarak Balıkesir grubu taşıma işlemlerini ticari bir araçla yapmaktadır. Buğday açısından ise yakıt maliyeti olarak $160 \mathrm{TL} /$ da oluşmaktadır. Bu nakliye gideri endüstriyel buğdayın verim miktarlarına göre karşılaştırıldığında yüksek bir fiyattır. Yerel buğdayın nakliye giderleri daha yüksek gözükmektedir.

Çizelge 8 İzmir İli Endüstriyel Buğday Nakliye Giderleri

\begin{tabular}{|c|c|}
\hline Nakliye Giderleri & Endüstriyel Buğday (TL/da) \\
\hline Ambara taşıma (dane) & - \\
\hline Pazara taşıma (dane) & 21,00 \\
\hline Ambara taşıma (saman) & - \\
\hline Pazara taşıma (saman) & $\mathbf{3 9 , 0 0}$ \\
\hline TOPLAM & \\
\hline Kaynak: İmir Il & \\
\hline
\end{tabular}

Kaynak: İzmir İl Gıda Tarım ve Hayvancılık Müdürlüğü; 2016

Maliyetler açısından kıyaslamak gerekirse yerel buğday üretimi endüstriyel üretime göre avantajlıdır. Öncelikle yerel buğday üretiminde hiçbir türlü kimyasal kullanılmadığından endüstriyel tarımda var olan bir çok maliyet oluşmamaktadır. Hayvan gübresi ise çok az tercih edilmektedir. Tercih edilse dahi yerelden temin edildiğinden kimyasal gübreye göre daha az maliyet oluşmaktadır. Genel olarak buğday tarımı kış aylarına denk geldiğinden her iki tarımsal faaliyet için de yoğun sulama yapılmamaktadır. Üretimde var olan işçilik ise gözlemlendiği üzere her iki tarımsal faaliyet açısından aynıdır. Nakliye süreçlerinde üretimler arası farklılık olsa da (kargo bedeli, ürünlerin değirmene götürülmesi vb.) yerel buğday üreticilerinin pazara kadar sürece dahil olması yerel buğday üretimini daha avantajlı kılmaktadır. Ayrıca yerel buğday satış fiyatlarının daha yüksek olması her türlü yerel buğday üretiminin ekonomik olarak daha avantajlı bir duruma getirmektedir.

Endüstriyel tarımın yarattığı yüksek maliyete karşılık düşük kâr sağlaması, buğday satışında araya giren aracının çok olması, yerel buğday üretimi yapan üreticilerin ve grupların oluşma aşamasındaki desteğin başlıca sebeplerindendir. Bunun dişında daha yüksek gelir elde etme, daha az masraf yaparak hem 
finansman sorununu hafifletmek hem de ürünün sel vb. ile yok olması veya ürün fiyatlarının düşük olması gibi risk ve belirsizliklere karşı daha yüksek bir dayanıklılık elde etme, daha lezzetli ürün tüketebilme, ot öldürücü ve diğer tarım ilaçları gibi sağlığa zararlı maddelerle temas etmeme, hayvanlar için daha fazla saman elde etme, vb. etkenler de sayılabilir.

\section{Sonuç}

1960'lar sonrası yeşil devrim denilen süreçte; bir yandan ıslah edilen buğdayların besin elementlerinde sağlığı olumsuz etkileyen değişiklikler olmuş, diğer yandan bu çeşitlerin daha yoğun sentetik tarım ilaçları ve kimyasal gübreler ile üretilmesi gerekmiştir. Buğdayın verimi artmış, gluten oranı yükselmiş, buğday tohumu da bir meta haline gelmeye başlamıştır. İnsanlar, hayvanlar ve bitkiler arasında uyumlu ve ekolojinin sağlığına hizmet eden bağlar kopmaya başlamıştır. Bu durum sadece insan sağlığı ve ekolojik yapıya darbeler indirmekle kalmamış, ekonomik ve sosyal açıdan da olumsuz gelişmelere yol açmıştır. Son yıllarda gerek dünyada gerekse de ülkemizde artan gluten içeriği ve gluten dahil diğer besin öğelerinin kimyasal yapısındaki değişimler ve kirleticilerle yüklenen buğday ve endüstriyel mayalarla üretilen ekmek ve bulgur gibi diğer ürünlerin birçok sağlık sorununa yol açtığına dair araştırmalar ve itirazlar yoğunlaşmıştır.

Bu durum ülkemizde ve dünyada üç ayrı davranışa yol açmıştır. Birinci görüşü ileri sürenler çölyak hastaları gibi dar bir grup dışında ciddi bir sorun olmadığını söylemektedirler. İkinci görüştekiler ise hiçbir buğday ürününün yenmemesini salık vermektedirler. Bu çalışmanın ilgilendiği üçüncü görüştekiler ise geleneksel buğday çeşitlerinden elde edilmiş ekşi maya ile üretilmiş ekmek ve bulgur gibi başka ürünlerin tüketilmesini bir çıkış yolu olarak önermektedirler. Bu tartışmalar ve gelişmeler ülkemizde de bazı üretici ve tüketici gruplarını geleneksel yerel buğdayların ve ekşi maya ile üretilmiş ekmeklerin üretilmesi ve tüketilmesi konusunda çabalar göstermelerine yol açmıştır.

Çanakkale grubu epey sayıda yerel buğday çeşidini ayrı ayrı üretmeyi, bunlardan ekşi maya ile ekmek ve bulgur yapmayı başarmıştır. Ürünler gıda grubu içinde dağıtılmaktadır. Bayramiç-Yeniköy grubu agroekolojik değerlere sahip yeni köylülerden (daha önce kentlerde profesyonel çalışan kişiler) oluşmuştur ve az sayıda üyesi arazide üretimi üstlenmişlerdir. Çanakkale grubu üretici üyelerinin ülke çapında bağları ve etkisi oldukça yüksektir. Balıkesir grubu ise buğday üretimini çoğunluğu dağ köylerinde olan çiftçilere bırakmışlardır. Ürünler göreli olarak iyi fiyatlarla çiftçilerden alınmakta, bulgur, kuskus gibi ürünler ve Balıkesir'de köylülerce ekşi maya ile üretilen ekmekler grup üyelerine, un da dahil aynı ürünler çevre illere ve gıda gruplarına yollanmaktadır. Bu grupta üretim ve tüketimin toplumsallaştırılması Çanakkale'den daha yüksektir. Köylü ve tüketici arasında daha iyi bağlar kurulmuştur. 
Kars grubu ise kurulan dernek aracıllğı ile 23 köyde buğday ve diğer ürünler açısından tam bir agroekolojik sistemi yerleştirmeyi başarmıştır. Toplumsallaşma ve derinleşme diğer iki gruptan daha yüksektir. Ulusal ve uluslararası etkileri de hayli yüksektir. Dernek sadece buğdayı değil, peynir, tıbbi bitkiler, kırsal turizm, ev bahçeleri gibi diğer alanlarda da agroekoloji sistemini çalıştığ köylerde hâkim kılabilmiştir. Özellikle Kars'ta yerel buğdaylardan, sentetik tarım ilaçları ve kimyasal gübre kullanılarak 1960 sonrası geliştirilmiş çeşitlerden daha iyi verim elde edilebilmiştir. Balıkesir köylerinde yerel buğdayların daha başarılı ve daha az riskli yetiştirilebildiği ve bu nedenle çiftçilerce tercih edildiği söylenebilir. Çanakkale'de ise yerel buğdayın verimi daha düşüktür. Her üç grupta da un, bulgur veya ekmekler daha iyi fiyatlarla satılabilmektedir. Yerel buğday üretenlerin daha düşük bir masraf ile daha risksiz buğday üretiminden memnun kaldıkları söylenebilir. Diğer yandan bu üreticiler ekmek, bulgur vb. ürünleri kendileri de tüketmektedirler. Köylüler bu ürünlerin lezzetinden memnundurlar ve sağlıklı kıldığı yönünde düşünceleri vardır.

Son olarak, yerel buğday, bunlardan elde edilmiş un ve ekşi maya ile yapılmış ekmeklerin yaygınlaştırılması için belediyeler ve kamu kuruluşlarının bazı müdahalelerde bulunmasına ihtiyaç vardır. Bunlar şöyle sıralanabilir:

Yerel buğday ve ekşi maya ile üretilmiş ekmek ve bulgurların üretilmesi ve tüketilmesi için fiyat ve vergi benzeri yollarla destek verilmesi ve bunun için alım yapmak üzere kooperatiflere finansman sağlanması,

Belediye ve kamunun bizzat ekmek fabrikası kurması ve agroekolojik sistemde üretilmiş yerel buğday alımı yapması,

Yoksullara yardım için, resmi kurumlar, okullar, ordu yemekhanelerinde kullanılmak üzere bu ürünlerin satın alınması,

Agroekoloji tarım sistemi içinde yerel buğday ve ekşi mayalı ekmek ve diğer ürünlerin üretimi için araştırma çalışmalarına destek verilmesi, ve

Sürdürülebilir buğday ve ekmek üretimi için yeni kriterler ve standartlar geliştirilmesi, buğday üretimi ve ekmek üretiminde bunların sıkı bir şekilde uygulanması.

\section{Kaynakça}

Akçura, Mevlüt, Onur Hocaoğlu, Hasan Kılıç, Kağan Kökten. “Karadeniz Bölgesine Ait Yerel Ekmeklik Buğday Hatlarının Tanedeki Besin Elementleri İçerikleri Yönünden Tescilli Ekmeklik Buğday Çeşitleri ile Karşılaştırılması". Türkiye 10. Tarla Bitkileri Kongresi, cilt 1, no. 1 (Konya, 2002), 53-60.

Aksoy, Zühre. "Biodiversity and Biotechnology in the Agriculture Sector". Environmentalism in Turkey Between Democracy and Development? içinde. Derleyen Fikret Adaman ve Murat Arsel, 235-249. Aldershot, Hants; Burlington, VT: Ashgate, 2005.

Brush, S. B. ve E. Meng. "The Value of Wheat Genetic Resources to Farmers in Turkey". Agricultural Values of Plant Genetic Resources içinde. Derleyen R. E. Evenson, D. Gollin ve V. Santaniello, 97-113. Wallington: CAB International, 1998.

Davis, William. Buğday Göbeği. Çeviren Ekin Duru. İstanbul: Pegasus Yayınları, 2014. 
Dohan, F. C., "Wheat 'Consumption' and Hospital Admissions for Schizophrenia during World War II: A Preliminary Report". The American Journal of Clinical Nutrition 18, no. 1 (Ocak 1966): 7-10.

FAO, Wheat Landraces in Farmers' Fields in Turkey: National Survey, Collection, and Conservation, 2009-2014. Mustafa Kan, Murat Küçükç̧ongar, Mesut Keser, Alexey Morgounov, Hafiz Muminjanov, Fatih Özdemir, Calvin Qualset (Ankara, 2015).

FAOSTAT, 2016. Production Quantities of Wheat by Country. http://faostat3.fao.org/ browse/Q/QC/E. Erişim tarihi 5 Mart 2016.

Gao, X., S. W. Liu, Q. Sun, G. M. Xia. "High Frequency of HMW-GS Sequence Variation Through Somatic Hybridization Between Agropyron Longatum and Common Wheat". Planta 213, no. 2 (Ocak 2010): 245-250.

Gökgöl, Mirza. Türkiye Buğdayları. Die Türkischen Weizen. 2. Cilt. İstanbul: Yeşilköy Tohum Islah Enstitüsü, 1939.

Karakoç, U. "Productivity and Structure in Turkish Agriculture 1950-1991". Yüksek Lisans Tezi, London School of Economics and Political Science, Londra, 2008.

Kimber, Gordon ve Moshe Feldman. Wild Wheat: An Introduction Special Report 353. Columbia: University of Missouri College of Agriculture, 1987.

Koçtürk, Osman Nuri. Açlık Korkusu. Ankara: TMMOB Ziraat Mühendisleri Odası, 2009.

Molberg, O., A. K. Uhlen, T. Jensen vd. "Mapping of Gluten T-cell Epitopes in the Bread Wheat Ancestors: Implications for Celiac Disease". Gastroenterology 128, no. 2 (Şubat 2005): 393-401.

Özkaya, Tayfun, "Kars'ta Güzel Şeyler Oluyor". http://www.yurtgazetesi.com.tr/karstaguzel-seyler-oluyor-makale,2809.html. Erişim tarihi 16 Kasım 2016.

Perkins, John H. Geopolitics and Green Revolution: Wheat, Genes, and the Cold War. New York: Oxford University Press, 1997.

Powell, W., E. P. Wilhelm, M. I. Boulton, T. E. S. Barber, A. J. Greenland. “Genotype Analysis of the Wheat Semidwarf Rht-B1b and Rht-D1b Ancestral Lineage". Plant Breeding 132, no. 6 (2013): 539-545.

Salalı, E. H. “Ege Bölgesi'nde Tarımsal Biyoçeşitliliğin Korunması ve Sürdürülebilir Kullanımı Açısından Yerel Buğday Çeşitlerinde Üretici Ve Tüketici Duyarlılıklarının Ölçülmesi". Doktora Tezi, Ege Üniversitesi, İzmir, 2013.

Schmidt, Klaus. Taş Çă̆ı Avcılarının Gizemli Kutsal Alanı, Göbekli Tepe, En Eski Tapınă̆ı Yapanlar. Çeviren Rüstem Arslan. İstanbul: Arkeoloji ve Sanat Yayınları, 2014.

Shewry, Peter R., Nigel G. Halford, Peter S. Belton, Arthur S. Tatham. "The Structure and Properties of Gluten: An Elastic Protein from Wheat Grain". Philosophical Transactions Royal Society London B 357, no. 1418 (Şubat 2002): 133-142.

TÜİK, 2016. Buğday İstatistikleri, http://tuikapp.tuik.gov.tr/.

Uhri, Ahmet. Boğaz Derdi: Arkeolojik, Arkeobotanik, Tarihsel ve Etimolojik Veriler Işı̆̆ı̆nda, Tarım ve Beslenmenin Kültü̈r Tarihi. İstanbul: Ege Yayınları, 2011.

Yingyin, Y., N. Zhongfu, Z. Yinhong, C. Yan, D. Yuhua, H. Zongfu, L. Zhiyong, S. Qixin. "Identification of Differentially Expressed Genes in Leaf and Root Between Wheat Hybrid and Its Parental Inbreds Using PCR-based cDNA Subtraction". Plant Molecular Biology 58 (2005): 367-384.

WWF. Türkiye'nin Buğday Atlası. İstanbul: Doğal Hayatı Koruma Vakfı, 2016. 